\title{
CEPAL Review
}

\author{
Director \\ RAUL PREBISCH
}

Technical Editor

ADOLFO GURRIERI

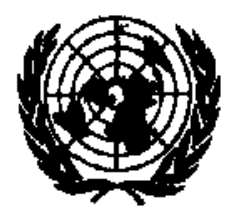

UNITED NATIONS

ECONOMIC COMMISSION FOR LATIN AMERICA SANTLAGO, CHILE / SECOND HALF OF 1976 


\section{CONTENTS}

Latin America in the possible scenarios of détente

José Medina Echavarrta

The revolt of the bankers in the international economy:

a world without a monetary system

Carlos Massad

Industrial development and employment: the experience of Asia and Latin American development strategy

Akio Hosono

The production structure and the dynamics of development

Gérard Fichet and Norberto González

Types of income concentration and political styles in Latip America

Jorge Graciarena

Some CEPAL publications

Notes and comments

A tribute to Oscar Varsavsky 
CEPAL REVIEW

Second half of 1976

\section{Industrial}

development and

employment:

the experience of

Asia and Latin

American

development

\section{strategy}

\section{Akio Hosono *}

In Latin America it is generally believed that the modern and traditional sectors of the economy are divergent and even incompatible, but in the light of the experience of Japan and China this assertion can be refuted. In the post-war period, Japan chose a style of development made up of both these sectors, which has promoted the parallel advance of industries of different size and capital intensity. Since 1958, China has followed the policy of "walking on two legs", which pursues the simultaneous and combined development of agriculture and manufacturing and, within the latter, of different sectors, levels of technology, and localities.

Both these processes were most successful in absorbing the considerable manpower existing in those countries: therefore, the author maintains that they should be known and studied in Latin America, where a large increase in the active population is expected in the next few decades.

-International Trade and Development Division, CEPAL.

\section{Introduction}

Latin America is expected to have 477 million inhabitants in 1990 and 613 million by the year $2000 .^{1}$ There is no doubt, therefore, that the development strategy adopted in the rest of the twentieth century should take very much into account the question of how to provide food and sources of employment, and considerably improve the level of living of the population, given the expected population growth.

In the search for a development strategy for Latin America it may be useful to know the development experience of some densely populated countries of Asia. Japan, with its 100 million inhabitants and mountainous territory which is smaller than that of the State of California, is the country that has most recently attained a degree of industrial development comparably with that of the European countries, but through a very different process from that of other developed countries, owing precisely to its plentiful manpower. China, with over 700 million inhabitants and a very limited area of arable land per head, adopted a very different style of development from that of the socialist European countries, since it was based on the policy of "walking on two legs" and on the rural industrialization and other policies.

A comparison of the main economic indicators of Latin America with those of the two Asian countries referred to may make it easier to appreciate the significance of their experience in the past 25 years and contribute towards finding an altemative development strategy for the next quarter of a century in Latin America (see table 1).

\footnotetext{
${ }^{1}$ CELADE, Boletín demográfico, No 17, January 1976.
} 
In the present study, the problems related to employment and its possible solutions are analysed from three angles: the characteristics of industrial development, the modernization of agriculture, and technological progress.

Table 1

LATIN AMERICA, BRAZIL, CHINA AND JAPAN: MAIN ECONOMIC INDICATORS (Millions of units)

\begin{tabular}{|c|c|c|c|c|c|c|c|c|}
\hline \multirow{2}{*}{ Indicators } & \multicolumn{2}{|c|}{ Latin America } & \multicolumn{2}{|c|}{ Brazil } & \multicolumn{2}{|c|}{ China } & \multicolumn{2}{|c|}{ Japan } \\
\hline & 1950 & 1970 & 1950 & 1970 & 1950 & 1970 & 1950 & 1970 \\
\hline Population (inhabitants) & 155 & 275 & 52 & 93 & $569^{a}$ & 842 & 83 & 104 \\
\hline Cultivated area (hectares) & $69^{b}$ & 85 & $25^{b}$ & 34 & $254^{\mathrm{a}}$ & $289^{c}$ & 6 & 6 \\
\hline $\begin{array}{l}\text { Production of cereals } \\
\text { (tons) }\end{array}$ & 36 & 91 & 14 & 37 & $154^{\mathrm{a}}$ & 240 & 15 & 15 \\
\hline $\begin{array}{l}\text { Electric power generation } \\
\text { (KWH) }\end{array}$ & 27 & 147 & 8 & 46 & & 60 & 47 & 360 \\
\hline Production of steel (tons) & 1.4 & 13 & 0.7 & 6 & 1 & 21 & 3 & 93 \\
\hline Value of exports (dollars) & 6313 & 13783 & 1364 & 2739 & & 2320 & 820 & 19318 \\
\hline
\end{tabular}

Note: This information is given for purely illustrative purposes. It includes approximate figures and some data which are not strictly comparable.

a1952.

bAverage for $1959-1961$.

c1965.

\section{Japan's experience ${ }^{2}$}

At the end of the Second World War, Japan faced a serious problem of redundant manpower brought about by repatriation from its former colonies and the territories it had occupied, the demobilization of approximately 6

\footnotetext{
${ }^{2}$ In Japan's industrial development process, the experience of most value to Latin America was in the period 1950-1970; it is on this period, therefore, that the statistical information and analysis for that country will be concentrated.
}

million members of the armed forces in 1946-1947, and the increase in its population due to the decline in the mortality rate. It should be recalled here that at the end of the 1940 s there were about 15 million persons employed or under-employed, and that in 1950 about 50 per cent of the labour force was engaged in agriculture. ${ }^{3}$

\footnotetext{
${ }^{3}$ Before the war (1940) the proportion was 41.5 per cent.
} 
In the ensuing 20 years (1950-1970) the labour force increased by over 15 million persons; those born during the post-war baby boom contributed to this increase in the final phase. Furthermore, there was a marked and continuing shift of manpower from the primary sectors (agriculture and fishing) involving around 10 million persons. Therefore, manufacturing, construction and other sectors had to absorb more than 25 million persons during that period.

It is surprising, therefore, to find that in spite of the situation prevailing at the beginning of the post-war period and the high increase in the labour force in the next few years, the abundance of manpower soon changed to a shortage, which was an important factor for the Japanese economy since superfluous manpower had been one of the most serious chronic problems before the war. ${ }^{4}$

The secret of this phenomenon undoubtedly lay in Japan's accelerated economic growth, which was basically due to industrial development. The manpower engaged in manufacturing increased from 6 million persons in 1950 to nearly 14 million in 1970 . If electricity, gas and water, transport and communications, and construction are also considered, the net increase in manpower absorbed by these sectors during the above period was 12.2 million persons (from 9 to 21.2 million). This increase represents 80.3 per cent of the total increase in the Japanese labour force during the period considered (see table 2).

\section{Characteristics of industrial development and the increase in employment}

How was manufacturing able to absorb so much manpower, particularly as Japan's industrial development was characterized by the expansion of the heavy and chemical industries, which are largely based on imported technology? It is a well-known fact that these industries, whose technology originated in countries suffering from a labour shortage, are generally unable to absorb manpower on any great scale.

Briefly, there can be said to have been parallel progress in both labourintensive and capital-intensive industries, which was due not only to the particular structure of Japanese manufacturing industry in which certain sub-sectors play an important role, but also to the co-existence and simultaneous development of enterprises of different sizes.

As noted earlier, Japan's post-war industrial development was predominantly characterized by the extraordinary expansion of the heavy and chemical industries. By the end of the 1950 s the share of both these types of

\footnotetext{
4 To analyse in more precise terms when and how this change occurred has been a subject of great interest to Japanese economists (see, for example, Ryoshin Minami, "The turning point in the Japanese economy", Quarterly Journal of Economics, August 1968). In the mid-1950s the employment problem was one of the country's main concerns. Officials of the Economic Planning Agency, in preparing the New Long-Term Economic Plan, considered that a minimum economic growth of 6 to 7 per cent was essential to be able to absorb 1.3 million new workers annually over the period 1957-1963, See Takafusa Nakamura, Sengo Nihonkeizai (The Japanese economy in the post-war period), Tokyo, 1968.
} 
Table 2

JAPAN: MANPOWER EMPLOYED BY THE MAIN ECONOAIC SECTORS

\begin{tabular}{|c|c|c|c|c|c|c|c|c|}
\hline Year & Total & $\begin{array}{c}\text { Agricul- } \\
\text { ture, } \\
\text { forestry } \\
\text { and } \\
\text { fishing }\end{array}$ & Mining & $\begin{array}{c}\text { Construc } \\
\text { tion }\end{array}$ & $\begin{array}{c}\text { Manufac- } \\
\text { turing }\end{array}$ & $\begin{array}{c}\text { Basic } \\
\text { services }\end{array}$ & $\begin{array}{l}\text { Commer- } \\
\text { ce, banks } \\
\text { and other } \\
\text { services }\end{array}$ & $\begin{array}{l}\text { Public } \\
\text { adminis- } \\
\text { tration }\end{array}$ \\
\hline \multicolumn{9}{|c|}{ Millions of persons } \\
\hline 1950 & 35.7 & 18.4 & 0.5 & 1.3 & 6.0 & 1.7 & 7.2 & 1.2 \\
\hline 1970 & 50.9 & 8.9 & 0.2 & 3.9 & 13.8 & 3.5 & 19.0 & 1.6 \\
\hline \multicolumn{9}{|c|}{ Variation (cumulative average annual rate) } \\
\hline $1950-1970$ & 1.79 & -3.57 & -4.38 & 5.82 & 4.24 & 3.72 & 4.97 & 1.48 \\
\hline
\end{tabular}

Soture: Statistical Office of Japan, Japan Statistical Yearbook, various issues.

Table 3

INDUSTRIALIZED COUNTRIES: SHARE OF HEAVY AND CHEMICAL INDUSTRIES IN MANUF ACTURING

(Per cent)

\begin{tabular}{|c|c|c|c|c|c|c|}
\hline & Japan & $\begin{array}{l}\text { United } \\
\text { States }\end{array}$ & $\begin{array}{l}\text { United } \\
\text { Kigndom }\end{array}$ & France & Italy & $\begin{array}{c}\text { Federal } \\
\text { Republic of } \\
\text { Germany }\end{array}$ \\
\hline \multicolumn{7}{|c|}{ Value added } \\
\hline 1955 & 45 & 63 & 62 & 59 & 55 & 57 \\
\hline 1965 & 64 & 64 & 65 & 61 & 61 & 60 \\
\hline \multicolumn{7}{|c|}{ Value of exports } \\
\hline 1961 & 53 & 83 & 78 & 71 & 62 & 86 \\
\hline 1968 & 73 & 87 & 77 & 74 & 64 & 84 \\
\hline
\end{tabular}

Sources: Production: Economic Planning Agency, Economic Survey of Japan, 1967.

Exports: Ministry of International Trade and Industry, Official report on foreign trade (in Japanese).

This is one of the reasons why the heavy and chemical industries were able to absorb a large proportion of manpower in Japan.
It should be noted, however, that all the aforementioned industries in which Japan has specialized, while requiring fairly low fixed capital per worker, 
industries ${ }^{5}$ in the total manufacturing value added had reached the same level as in the major European countries and the United States (see table 3).

Moreover, their share is unusually great in relation to the size of the population and per capita income. ${ }^{6}$

It should be noted, furthermore, that among the various heavy and chemical

\footnotetext{
$s$ The heavy and chemical industries comprise the chemical industry (including the petroleum and coal products industries and the petrochemical industry), the metals industry, and the machinery and equipment industry (including optical and precision instruments and equipment), according to the normal definition of the Economic Planning Agency of the Japanese Government, which is used in the present study unless otherwise indicated. The term "heavy and chemical industries" is very common in official circles and among Japanese economists and constituted a general incustrial policy aim in the period following the Second World War. Some economists admit, however, that the term is not always clear and tends to represent a rather vague concept. In this respect, see, for example, the article by Miyohei Shinohara on "Structural change in Japan's manufacturing industry in the post-war period", Shinohara and Fujino (ed.), Nihon no Keizai Seicho (Japan's economic growth), Tokyo, 1967. It is widely accepted, however, that the heavy and chemical industries have the common characteristics of greater elasticity of demand for their products in relation to the growth of income, a faster rate of technological development and a bigger impact on other branches of industry.
}

${ }^{6}$ According to a report on foreign trade by the Ministry of International Trade and Industry (1972), the value added in the heavy and chemical industries in 1960 was more than double the normal value added for the size of population and per capita national product calculated on the basis of a standard development model with data for 22 countries. In 1960 the corresponding figures for the metals, electrical machinery, machinery other than electrical, and transport equipment industries were $4.83,3.06,3.52$ and 3.32 times greater, respectively. industries, it was the labour-intensive industries that expanded most rapidly.' They included industries producing eleotronic equipment, precision instruments, and electrical and textile machinery. Although these activities require advanced technology, they need less investment per worker than the metals, motor-vehicle and petrochemical industries. Fixed capital investment per person employed in the electrical machinery industry is a fourteenth part of that required in the petroleum products industry and less than one-third of that needed in the chemical and steel industries. It is even less than that observed in the textile and food industries in establishments with 20 workers or more (see table 4).

Moreover, the capital required for the manufacture of textile machinery, sewing-machines, cameras, and watches and clocks is even less than that needed in the electrical machinery industry. A similar situation is observable in the transport equipment industry: the fixed capital per worker required for the construction of ships is less than the average needed in manufacturing industry and is less than half that required by the motor-vehicle industry. It is common knowledge that Japan specializes in shipbuilding and supplies over 50 per cent of the world's ships.

\footnotetext{
${ }^{7}$ For illustrative purposes only, a comparison is made here of the structure of the machinery industry in the United States and Japan. In the latter country the industries producing electrical machinery, ships and some light machines, the production of which has been specially promoted, absorb 47.5 per cent of the persons employed in the metal manufactures and machinery industries and generate 45.2 per cent of the total value added in this sector. The proportions in the United States are considerably lower: 35.8 and 32.9 per cont, respectively.
} 
Table 4

JAPAN: MANPOWER EMPLOYED, FIXED CAPITAL AND VALUE ADDED IN MANUF ACTURING, $1966^{\circ}$

\begin{tabular}{lccc}
\hline & $\begin{array}{c}\text { Number of } \\
\text { persons } \\
\text { employed } \\
\text { (thousands) }\end{array}$ & $\begin{array}{c}\text { Value added } \\
\text { per worker } \\
\text { (millons } \\
\text { of yen) }\end{array}$ & $\begin{array}{c}\text { Fixed capital } \\
\text { per worker } \\
\text { (millions } \\
\text { of yen) }\end{array}$ \\
\cline { 2 - 4 } Total, manufacturing industry b & 7434 & 1.30 & 1.15 \\
Food & 674 & 1.24 & 1.03 \\
Textiles & 880 & 0.75 & 0.63 \\
Chemicals and petrochemical products $c$ & 457 & 2.59 & 2.81 \\
Petroleum and coal products & 33 & 3.53 & 8.73 \\
Iron and steel & 451 & 1.60 & 3.10 \\
Non-ferrous metals & 159 & 1.88 & 2.11 \\
Metal manufactures & 420 & 1.10 & 0.71 \\
Machinery except electrical & 741 & 1.29 & 0.84 \\
Electrical machinery & 839 & 1.18 & 0.62 \\
Transport equipment & 634 & 1.54 & 1.09 \\
Precision instruments & 159 & 1.05 & 0.50 \\
\hline
\end{tabular}

Source: Ministry of International Trade and Industry, Kogyo Tokeihyo (Industrial statistics) 1966, Tokyo, 1968.

a Establishments with 20 workers or more.

bIncluding other manufacturing sub-sectors.

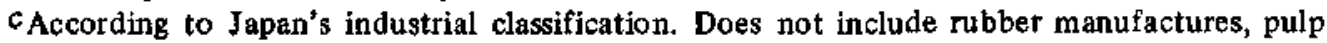
processing, etc.

obtain a considerably higher value added per worker than the food, textile, wood and leather manufactures and other industries (see table 4).

Japan's greater specialization in these industries is strikingly reflected in the structure of its exports. Official statistics show that in 1964 the products of highly labour-intensive industries (excluding the production of transport equipment) represented approximately 30 per cent of Japan's total exports and accounted for 52 per cent of the total value of exports of manufactures produced by the heavy and chemical industries, while the corresponding proportions for the Federal Republic of Germany, France and Italy were around 30 per cent. In contrast, the products of highly capitalintensive industries (including transport equipment) represented only 28 per cent of total exports from Japan, compared with over 45 per cent of those of the three European countries considered. This difference is even more pronounced if ships, the production of which has 
Table 5

INDUSTRIALIZED COUNTRIES: EXPORTS OF MANUFACTURES ACCORDING TO THE CHARACTERISTICS OF THE INDUSTRIES, 1964a

(Per cent)

\begin{tabular}{|c|c|c|c|c|}
\hline & Jopan & $\begin{array}{l}\text { Federal } \\
\text { Republic of } \\
\text { Germany }\end{array}$ & France & ' Italy \\
\hline Products of the heavy and chemical industries & 57.4 & 80.5 & 69.4 & 59.7 \\
\hline Highly capital-intensive industries & 27.6 & 56.5 & 44.6 & 43.5 \\
\hline Heavy equipment and machinery & 18.8 & 44.6 & 31.8 & 33.7 \\
\hline Ships & 7.4 & 1.4 & 1.2 & 1.0 \\
\hline Other products & 8.8 & 11.9 & 12.8 & 9.8 \\
\hline Relatively labour-intensive industries & 29.9 & 24.1 & 25.4 & 16.2 \\
\hline Light machinery & 12.7 & 10.2 & 6.1 & 6.9 \\
\hline Other products & 17.2 & 13.9 & 19.3 & 9.3 \\
\hline Products of light industries & 42.6 & 19.5 & 30.0 & 40.3 \\
\hline
\end{tabular}

Source: Ministry of International Trade and Industry, Official report on foreign trade, 1965.

a According to the classification prepared by the Japanese Ministry of International Trade and Industry, by SITC groups (three digits).

somewhat similar characteristics to the first group of industries, are excluded (see table 5).

In the period 1955-1965 the production and exports of the more labourintensive heavy and chemical industries increased more rapidly than those of other industries (see tables 6 and 7 ). In other words, the industries which grew fastest had the advantage of being less capital-intensive, yet attained a high level of productivity and a high rate of exports. In certain periods, moreover, some of these industries substantially increased their productivity without increasing their capital in proportion to the manpower employed. ${ }^{\mathrm{s}}$ This situation is attributable to various rationalization measures and appreciable technological progress based on the transfer and adaptation of foreign technology (see table 8).

${ }^{6}$ In the industries producing machinery other than electrical, for example, the index of persons employed in 1960 rose to 193 $(1950=100)$ and the productivity index to 132 , while the index of fixed capital per worker remained at 92.5 . Even more striking results were obtained in the electrical machinery industry, since the index of persons employed rose to 287.3 in 1960 and the procuctivity index to 191.5, while the index of fixed capital per worker remained constant at 101 . 
Table 6

\section{JAPAN: COMPOSITION AND GROWTH OF EXPORTS OF MANUFACTURES, BY GROUPS OF PRODUCTS CLASSIFIED ACCORDING TO \\ CAPITAL INTENSITY ${ }^{a}$}

(Per cent)

\begin{tabular}{|c|c|c|c|c|}
\hline \multirow{2}{*}{ Groups of products } & \multicolumn{2}{|c|}{ Composition } & \multicolumn{2}{|c|}{$\begin{array}{l}\text { Cumulative annual } \\
\text { growth rates }\end{array}$} \\
\hline & 1955 & 1965 & $\begin{array}{l}1956 \\
1960\end{array}$ & $\begin{array}{r}1961- \\
1965\end{array}$ \\
\hline \multicolumn{5}{|c|}{ Highly capital-intensive industries } \\
\hline $\begin{array}{l}\text { Products of the heavy and } \\
\text { chemical industries }\end{array}$ & 28 & 31 & 10.6 & 24,6 \\
\hline Products of light industries & 39 & 26 & 15.2 & 8.4 \\
\hline \multicolumn{5}{|c|}{ Highly labour-intensive industries } \\
\hline $\begin{array}{l}\text { Products of the heavy and } \\
\text { chemical industries }\end{array}$ & 15 & 35 & 28.5 & 24.0 \\
\hline Products of light industries & 18 & 8 & 10.3 & 2.9 \\
\hline $\begin{array}{l}\text { Exports of manufactures as a } \\
\text { percentage of total exports }\end{array}$ & 89 & 95 & - & - \\
\hline
\end{tabular}

Source: Economic Planning Agency, Economic Survey of Japan, 1967.

aThe manufactures are classified according to the fixed capital per worker used to produce the article concemed, excluding foodstuffs.

\section{The role of small and medium - scale industry}

Another important factor accounting for the extraordinary absorption of manpower by manufacturing industry was the parallel development of small and medium-sized enterprises and large-scale enterprises in both the heavy and chemical industries and light industry. The co-existence of industrial establishments of different sizes in Japan is known as "dual structure". At the beginning of the industrial boom, investment was concentrated in the large-scale industries, and particularly in the heavy and chemical industries. The small and medium-sized industries also grew steadily throughout the period and, although their relative share in the value added declined somewhat, the rate of growth of their output was exceedingly high.

The most important feature of this process was that, in absolute figures, these industries absorbed considerable manpower. According to the manufacturing censuses taken in the period 1955-1965, the number of persons employed by small and medium-scale 
Table ?

JAPAN: RRODUCTION OF MANUFACTURES, BY GROUPS OF PRODUCTS CLASSIFIED ACCORDING TO CAPITAL INTENSITYa

(Per cent)

\begin{tabular}{|c|c|c|c|c|c|c|}
\hline \multirow[t]{2}{*}{ Groups of products } & \multicolumn{2}{|c|}{ Composition } & \multicolumn{2}{|c|}{$\begin{array}{c}\text { Cumulative annual } \\
\text { growth rates }\end{array}$} & \multicolumn{2}{|c|}{$\begin{array}{l}\text { Value of imports } \\
\text { compared with } \\
\text { domestic } \\
\text { production }^{b}\end{array}$} \\
\hline & 1955 & 1965 & $1956-1960$ & $1961-1965$ & 1955 & 1965 \\
\hline \multicolumn{7}{|l|}{ Highly capital-intensive industries } \\
\hline $\begin{array}{l}\text { Products of the heavy and } \\
\text { chemical industries }\end{array}$ & 37.7 & 34,6 & 17.8 & 13.7 & 5.4 & 5.4 \\
\hline Products of light industries & 19.6 & 17.4 & 16.8 & 13.9 & 3.7 & 3.0 \\
\hline \multicolumn{7}{|l|}{ Highly labour-intensive industries } \\
\hline $\begin{array}{l}\text { Products of the heavy and } \\
\text { chemical industries }\end{array}$ & 25.6 & 36.6 & 27.3 & 14.9 & 0.8 & 1.5 \\
\hline Products of light industries & 17.1 & 11.4 & 14.0 & 10.3 & 0.5 & 0.9 \\
\hline
\end{tabular}

Source: Economic Planning Agency, Economic Survey of Jopan, 1967.

asee table 6.

bValue of imports divided by the sum of the value of imports and domestic production.

industry ${ }^{9}$ increased by 2.81 million, while the number of persons employed by large-scale industry grew by 1.61 miliion. The high percentage of manpower absorbed by small and medium-scale industry in Japan is also clear from a comparison with other countries (see tables 9 and 10).

The Japanese small and mediumsized industries may be classified in three major groups: producers of consumer goods; those supplying large-scale enterprises with raw materials, components and other inputs; and local industries

${ }^{9}$ According to the legislation in force in Japan, small and medium-scale enterprises are considered to be such industrial establishments as employ less than 300 workers. specializing in certain articles, particularly for export.

Generally speaking, the large-scale enterprises specialized in activities in which they were most likely to achieve a high level of productivity with their larger scale of production, substantial investment and modern techniques. Japan has a great many enterprises that are on a par with or even ahead of European enterprises in terms of capital invested per worker, productivity per worker, etc. ${ }^{10}$ In contrast, investment in small and medium-sized enterprises was

\footnotetext{
${ }^{10}$ An interesting analysis on the subject appeared in Economic Planning Agency, Economic Survey of Japan, 1967, Tokyo, 1968.
} 
Table 8

JAPAN: INCREASE IN PRODUCTIVITY AND LEVEL OF WAGES IN MANUFACTURING, BY GROUPS OF PRODUCTS CLASSIFIED ACCORDING TO

CAPITAL INTENSITY ${ }^{a}$

\begin{tabular}{|c|c|c|c|c|c|}
\hline \multirow[t]{2}{*}{ Groups of products } & \multicolumn{2}{|c|}{$\begin{array}{l}\text { Labour productivity } \\
\text { (cumulative annual } \\
\text { growth rates) }\end{array}$} & \multicolumn{2}{|c|}{$\begin{array}{l}\text { Level of woges } \\
\text { (1 000 yen } \\
\text { per year })\end{array}$} & \multirow{2}{*}{$\begin{array}{c}\begin{array}{c}\text { Increase in } \\
\text { mages } \\
\text { (cumulative } \\
\text { annual }\end{array} \\
\text { growth rates } \\
\begin{array}{l}1956 . \\
1965\end{array}\end{array}$} \\
\hline & $\begin{array}{l}1956 \\
1960\end{array}$ & $\begin{array}{l}1961- \\
1965\end{array}$ & 1955 & 1965 & \\
\hline \multicolumn{6}{|c|}{ Highly capital-intensive industries } \\
\hline $\begin{array}{l}\text { Products of the heavy and } \\
\text { chemical industries }\end{array}$ & 9.6 & 10.3 & 217 & 491 & 8.5 \\
\hline Products of light industries & 7.8 & 8.9 & 126 & 354 & 8.8 \\
\hline \multicolumn{6}{|c|}{ Highly labour-intensive industries } \\
\hline $\begin{array}{l}\text { Products of the heavy and } \\
\text { chemical industries }\end{array}$ & 12.5 & 9.6 & 199 & 464 & 10.9 \\
\hline Products of light industries & 7.7 & 6.9 & 110 & 293 & 10.3 \\
\hline
\end{tabular}

Source: Economic Planning Agency, Economic Survey of Japan, 1967.

asee table ?.

Table 9

JAPAN: MANPOWER EMPLOYED AND VALUE ADDED IN THE MANUFACTURING SECTOR, BY SIZE OF ENTERPRISE

(Percentage distribution)

\begin{tabular}{|c|c|c|c|c|c|c|}
\hline & \multicolumn{3}{|c|}{1956} & \multicolumn{3}{|c|}{1966} \\
\hline & $\begin{array}{c}\text { Light } \\
\text { industry }\end{array}$ & $\begin{array}{l}\text { Heavy and } \\
\text { chemical } \\
\text { industries }\end{array}$ & Total & $\begin{array}{c}\text { Light } \\
\text { industry }\end{array}$ & $\begin{array}{l}\text { Heavy and } \\
\text { chemical } \\
\text { industries }\end{array}$ & Total \\
\hline \multicolumn{7}{|c|}{ Manpower employed } \\
\hline Plants with less than 300 workers & 82.9 & 55.6 & 72.3 & 82.2 & 54.5 & 69.7 \\
\hline Plants with 300 workers or more & 17.1 & 44.4 & 27.7 & 17.8 & 45.5 & 30.3 \\
\hline \multicolumn{7}{|c|}{ Value added } \\
\hline Plants with less than 300 workers & 65.6 & 38.0 & 51.1 & 71.8 & 39.4 & 53.5 \\
\hline Plants with 300 workers or more & 34.4 & 62.0 & 48.9 & 28.2 & 60.6 & 46.5 \\
\hline
\end{tabular}

Source: Economic Planning Agency, Economic Survey of Japan, 1968. 
Table 10

INDUSTRIALIZED COUNTRIES: PERSONS EMPLOYED IN MANUFACTURING, BY SIZE OF ENTERPRISE, 1958

(Percentage distribution and number of persons employed)

\begin{tabular}{lcccc}
\hline Size of enterprise & Japan & United States & Unted Kingdom & $\begin{array}{c}\text { Federal } \\
\text { Republic of } \\
\text { Germany }\end{array}$ \\
\hline Less than 100 workers & 58.4 & 27.0 & 20.2 & 48.4 \\
100.499 workers & 19.7 & 30.2 & 31.6 & 22.9 \\
S00 workers or more & 21.9 & 42.8 & 48.1 & 28.7 \\
$\begin{array}{l}\text { (Total number of persons } \\
\text { employed, thousands) }\end{array}$ & $(6664)$ & $(15394)$ & $(7680)$ & $(9932)$ \\
\hline
\end{tabular}

Source: Economic Planning Agency, Economic Sturvey of Japan, 1965.

a1955.

generally smaller and they continued to absorb a very high proportion of labour.

Some examples are given below.

Various indicators show that the scale and technology adopted for steel production in Japan were far superior to those used in the United States and the European countries, ${ }^{11}$ The daily production of iron in blast furnaces in 1966 was 1644 tons compared with 1268 tons in the United States, and was more than twice the average for the major European countries. Another important indicator is the use of the LD converter. That same year, 55 per cent of Japan's steel output was produced in LD converters, compared with 17.4 per cent in the

\footnotetext{
${ }^{11}$ See the official report on foreign trade, 1967 (in Japanese) of the Ministry of international Trade and Industry of Japan.

${ }^{12}$ The $L D$ converter was introduced in Japan in 1957, much earlier than in other countries. The largest blast furnace in the world, with a daily capacity of 4500 tons, has been in use in this country since 1966.
}

United States and 19.1 per cent in the Federal Republic of Germany. ${ }^{12}$ Moreover, production of taw steel per worker was 160 tons in 1966, almost equalling the United States output, It is a well-known fact that the Japanese steel industry has for some years had the lowest production costs.

Although steel was produced almost exclusively by large-scale industries, nearly 60 per cent of all steel products were manufactured by small and medium-sized industries. In the case of the forging and casting of steel and the casting of iron the proportion was over 70 per cent (see table 11).

The textile industry provides an even clearer example. With the vigorous expansion of the manufacture of synthetic fibres, which requires substantial investment and modern techniques and absorbs less manpower than the production of cotton textiles, millions of small and medium-sized dyeing plants and spinning mills continued to employ large numbers of workers and adapted their 
Table 11

JAPAN: PERSONS EMPLOYED AND VALUE ADDED IN THE STEEL INDUSTRY, BY SIZE OF ENTERPRISE, 1966

(Percentage distribution and absolute values)

\begin{tabular}{|c|c|c|c|c|c|c|}
\hline \multirow{3}{*}{ Total, steel industry $b$} & & \multicolumn{3}{|c|}{ Size of plant } & \multicolumn{2}{|c|}{ Total } \\
\hline & & $\begin{array}{c}\text { Less than } \\
100 \\
\text { workers }\end{array}$ & $\begin{array}{l}\text { I00-299 } \\
\text { workers }\end{array}$ & $\begin{array}{c}300 \\
\text { workers } \\
\text { or more }\end{array}$ & $\begin{array}{c}\text { Percent- } \\
\text { ages }\end{array}$ & $\begin{array}{c}\text { Absolute } \\
\text { values }^{a}\end{array}$ \\
\hline & & & & & & \\
\hline & A: & 24.6 & 12.8 & 62.6 & 100 & 485 \\
\hline & B: & 18.0 & 10.8 & 71.2 & 100 & 743 \\
\hline $\begin{array}{l}\text { Production of iron by blast } \\
\text { furnace }\end{array}$ & A: & 0.0 & 0.0 & 100.0 & 100 & 148 \\
\hline Rolled steel products & A: & 0.9 & 7.5 & 91.6 & 100 & 81 \\
\hline $\begin{array}{l}\text { Steel products (tubes, bars, } \\
\text { wire rod, etc.) }\end{array}$ & $\mathbf{A}:$ & 32.0 & 27.6 & 40.4 & 100 & 80 \\
\hline $\begin{array}{l}\text { Forging and casting of steel } \\
\text { (forged or cast steel products) }\end{array}$ & A: & 39.5 & 25.4 & 35.1 & 100 & 34 \\
\hline $\begin{array}{l}\text { Casting of iron (cast iron } \\
\text { products) }\end{array}$ & A: & 61.5 & 14.6 & 23.9 & 100 & 95 \\
\hline
\end{tabular}

Source: Ministry of International Trade and Industry, Kogyo Tokelhyo (Industrial statistics), 1966.

Note: A: persons employed; B: value added.

a: thousands of persons; B: thousands of millions of yen.

bincluding other sub-sectors.

technology to the use of synthetic material.

In the aforementioned report on foreign trade, ${ }^{13}$ it is considered that the factors which enabled Japan to become the leading exporter of synthetic fibre in all the stages of its manufacture (filament, fibre, yarn and fabric) in 1965 were: (i) investment in plants for the large-scale production of raw material, thus making it posible to increase productivity and obtain a large enough physical production capacity to leave a

\footnotetext{
${ }^{13}$ Ministry of International Trade and Industry, op. cit.
}

considerable margin for export; (ii) utilization of the technological experience gained in the use of natural fibres for the manufacture of synthetic textile products (dyeing plants, spinning mills, etc.); and (iii) use of the established channels for marketing Japan's traditional textile exports.

In connexion with synthetic fibre textiles, mention must be made of the petrochemical industry, which produces the raw material. Considerable amounts were invested and advanced techniques were introduced at an accelerated pace in this industry, as in the case of steelmaking. The government policy established in 1955 to promote this 
industry was a highly important step in orienting and promoting its expansion. According to the above-mentioned report on foreign trade ${ }^{14}$ since 1963 Japan's total production capacity has been the largest in the world except for that of the United States; in 1965 the scale of production of ethylene per plant was 107000 tons, second only to the United States output. In 1967 the Government decided to promote only the installation of petrochemical complexes with a capacity of not less than 300000 tons of ethylene.

There are several other cases of division of labour between large-scale enterprises and small and medium-sized enterprises, e.g., the motor-vehicle, shipbuilding and non-ferrous metals industries. The major motor-vehicle industries reached a scale of production equal to that of the European countries, which enabled them to invest considerable amounts in bodywork dies, transfer machines, etc.; the small and mediumsized industries, on the other hand, specialized in certain motor-vehicle parts (see table 12).

To sum up, the large-scale enterprises which were able to take full advantage of the new techniques were completely modernized, and they left the small and medium-sized industries a broad field in which it was still advantageous to use considerable labour and less capital and did not generally compete with them.

Consequently, in the process of rapid industrial growth and structural changes in the manufacturing sector, with emphasis on the heavy and chemical industries, enterprises of different sizes showed almost parallel growth. Small and medium-scale industry used ever cheaper and better basic inputs (steel,

${ }^{14} \mathrm{Ibid}$. petroleum products, synthetic raw materials, non-ferrous metals and electric power) produced by the large-scale industries, and they in turn supplied the components and other inputs required by the large industries; thus their scale of production increased as the enterprises which absorbed their products expanded.

This process is borne out by two interesting facts. First, trade in products between large-scale enterprises and small and medium-scale enterprises increased. A study based on input-output matrices showed that at the beginning of the period considered (1951-1955) the sales of small and medium-sized enterprises were destined mainly for final consumption. The same analysis in 1960 showed that there had been an appreciable increase in sales by those enterprises to the major enterprises, and likewise in sales among themselves. Sales by major enterprises to small and medium-scale enterprises also increased considerably. ${ }^{15}$

The simultaneous development of enterprises of different sizes is also evident from the indirect exports of small and medium-sized enterprises. Approximately 18 per cent of Japan's total exports of electrical machinery represent indirect exports, i.e., parts incorporated in articles exported by large-scale enterprises but originally produced by small and medium-sized enterprises. The proportions for transport equipment, precision instruments and other machinery are roughly 16 per cent, 10 per cent and 10 per cent, respectively. The average for all manufacturing industry is

\footnotetext{
${ }^{15} \mathrm{~S}$. Okita and others (ed.), The Japanese economy: Present situation and prospects (in Japanese), Tokyo, 1965.
} 
Table 12

\section{JAPAN: PERSONS EMPLOYED AND V ALUE ADDED IN THE MOTOR-VEHICLE INDUSTRY, BY SIZE OF ENTERPRISE}

(Percentage distribution and absolute values)

\begin{tabular}{|c|c|c|c|c|c|c|}
\hline & & \multicolumn{3}{|c|}{ Size of plant } & \multicolumn{2}{|c|}{ Total } \\
\hline & & $\begin{array}{l}\text { Less than } \\
100 \\
\text { workers }\end{array}$ & $\begin{array}{l}100-499 \\
\text { workers }\end{array}$ & $\begin{array}{c}500 \\
\text { workers } \\
\text { or more }\end{array}$ & $\begin{array}{c}\text { Percent- } \\
\text { ages }\end{array}$ & $\begin{array}{c}\text { Absolute } \\
\text { valuet }\end{array}$ \\
\hline \multicolumn{7}{|c|}{ Total motor-vehicle industry } \\
\hline & 1962: A & 28.5 & 24.1 & 47.4 & 100 & 324 \\
\hline & B & 12.2 & 14.8 & 73.0 & 100 & 404 \\
\hline & 1966: A & 26.0 & 21.0 & 53.0 & 100 & 456 \\
\hline & $\mathbf{B}$ & 13.3 & 13.6 & 73.1 & 100 & 690 \\
\hline \multicolumn{7}{|c|}{ Production of motor vehicles } \\
\hline and bodywork & 1962: A & 4.9 & 11.1 & 84.0 & 100 & 121 \\
\hline & 1966: A & 5.1 & 5.8 & 89.1 & 100 & 158 \\
\hline \multicolumn{7}{|c|}{ Production of motor-vehicle } \\
\hline components & 1962: A & 42.5 & 31.8 & 25.7 & 100 & 203 \\
\hline & 1966: A & 37.7 & 27.9 & 34.4 & 100 & 293 \\
\hline
\end{tabular}

Source: Ministry of International Trade and Industry, Kogyo Tokeihyo (Industrial statistics), 1962 and 1966.

Note: A: Persons employed; B: Value added.

aThe figures for 1962 exclude establishments with three workers or less.

$b_{A}$; Thousands of persons; B: Thousands of millions of yen.

7.9 per cent. ${ }^{16}$ These percentages indicate a slightly rising trend. Direct and indirect exports of small and medium-sized enterprises represented 54 per cent of Japan's total exports of manufactures in 1966.

Lastly, attention is drawn to a group of small and medium-sized enterprises

16 See "Export promotion in Japan and its application to Latin America", Economic Bulletin for Latin America, Vol. XV, No 1, table 16 (United Nations publication, Sales No E. 70.IL.G.6). which are engaged in the production of export articles and are installed in different parts of the country according to their line of specialization. They include industries producing silk fabrics, musical instruments, steel cutlery, knives, umbrellas, skis and other sports items, binoculars, tiles, chinaware and ceramics, furniture, spectacles, toys, bicycles, cigarette lighters, articles of antimony, precious stones, tools, etc. There are 346 localities specializing in the production of specific articles, 120 of which export a high proportion of their total output. According to an 
official report on these 120 localities, ${ }^{17}$ their industries employ over 570000 persons and in 1970 they exported, on average, 41.6 per cent of their total output, which is much higher that the average for small and medium-sized enterprises in general (approximately 8 per cent).

Most of these localities are in rural areas and an estimated 70 per cent of the persons employed in the industries established there were originally rural workers usually living in the same area. It should also be noted that in over 50 per cent of the localities the boom in production took place in the 1960s, although the majority of them have existed since before the war. Although the industries established in these localities do not need to produce on a large scale or invest large amounts, they do require considerable labour and a certain level of specialized techniques. Most of the articles they manufacture are also produced by small and medium-scale industry in other countries, but the interesting feature about Japan is that these industries are concentrated in different parts of the country according to the articles they produce.

The industries thus established have the following advantages: ${ }^{18}$

(a) There is always a wide range of sizes, designs, colours, qualities, etc., to be found in the individual localities, since the same type of article is produced in each. These industries are the most suited to the production of articles of which a great variety is required.

${ }^{17}$ Ministry of International Trade and Industry, Chushokigyo Hakusho (Official report on small and medium-scale enterprises, 1971) Tokyo, 1972.

${ }^{18}$ Ibid. (b) Final consumers or importers identify the articles by the name of the locality, which helps to stabilize sales. Since the articles are produced on a small scale, it is not easy for the brands of the individual producers to become known, as in the case of products of large-scale enterprises. At the same time, owing to the concentration of manufacturers it is easier to establish an efficient system of marketing.

(c) In many cases the enterprises can specialize in certain components or sub-processes in the manufacture of the product of the locality concerned, thereby achieving a more advanced degree of specialization and higher productivity.

(d) It is also possible to develop common activities in connexion with marketing the products, make joint purchases of materials and machinery, carry out joint technical research, etc.

In Japan, criticisms were levelled at a style of industrial development which permitted the simultaneous expansion of enterprises of different sizes, but no clear alternative has been suggested. Basically, the criticism referred not to the co-existence of large-scale enterprises and small and medium-scale enterprises, but to the considerable gap that existed, and still exists, between the two types of enterprises as regards productivity and wages. These gaps have generally been due to the small volume of investment and limited introduction of technology in the small and medium-sized enterprises, owing, among other factors, to the industries' restricted access to bank financing and their limited self-financing capacity.

It is important to note, however, that as industrialization advances these differences began to shrink. The increase in productivity per worker was greater in the small and medium-sized industries 
than in the major industries in 1961-1966, whereas in 1956-1961 the opposite had occurred. ${ }^{19}$ Likewise, in the period 1962-1970, for which more detailed figures are available, the productivity increase in the smaller enterprises (employing 20 to 299 workers) was greater than in the larger enterprises (over 300 workers). It should also be noted that even in the main branches of the machinery industry (electrical machinery, machinery other than electrical, transport equipment) the productivity of the smaller enterprises increased by more than that of the major enterprises (see table 13).

At the same time, the differences in wages according to the size of enterprise diminished, and have practically disappeared in the case of the young workers in the last few years.

The increase in productivity of the small and medium-sized enterprises is attributable to the increasing expansion of investment and the introduction of technology. Although at the outset these enterprises were unable to invest as much as the large-scale enterprises, in subsequent years their investment grew more rapidly. ${ }^{20}$

\footnotetext{
${ }^{19}$ In the period 1961-1966 the productivity increase in the smaller enterprises of the heavy and chemical industries was 171.3 per cent, compared with 161.4 per cent in the larger enterprises (see "Export promotion in Japan. ..", op. cit., table 13).

${ }^{20}$ The level of fixed capital investment by the small and medium-sized enterprises was 3.37 times higher in 1969 than in 1961. The figure for large-scale enterprises was 2.33 times. In this case, small and medium-sized enterprises were considered to be those with a capital of between 2 million and 50 million yen, and large-scale enterprises those with a capital of 50 million yen or more.
}

The rapid rise in the investment of the small and medium-sized enterprises was caused by a number of factors. In the first place, more funds, both in absolute and relative terms, were available from the private financial institutions ${ }^{21}$ set up for such companies: these resources represented about 11 per cent of the total funds of Japanese financial institutions in the middle of the 1950s, and rose to 16 per cent by the middle of the following decade. Furthermore, the Finance Corporation for Medium and Small Enterprises, a semi-public body, increased its financing. In addition, these companies were also able to make use of the increasing amount of financing offered by the commercial banks, particularly in periods of recession when the big companies were not interested in making large-scale investments.

Moreover, according to various indicators the medium and small enterprises made considerable technological progress as a result of the introduction of more foreign technology and of greater investment in technological research. Still more important for their progress was the assistance they received from State and provincial technological insticutes and the technological co-operation provided by the large enterprises. The technological institutes set up throughout the country, primarily to serve medium and small industry, specialized in research connected with the industrial activity of their own zone, such as the manufacture of china, iron casting, dyeing and design of silk fabrics, etc.

The large companies helped to improve the technology of the compa-

\footnotetext{
${ }^{21}$ Including the Central Co-operative Bank for Commerce and Industry, credit associations (Shinyo Kinko) and the mutual loan and savings banks.
} 
nies providing their components or inputs through various forms of co-operation: loan of specialists, exchange of experience, contracts for the transfer of technology, etc.

One interesting indicator is the increase in the contractual transfer of technology between medium and small enterprises and large companies. Payments by the former to the latter under this heading amounted to 1.7 million dollars in the two years 1966-1967. It should be stressed that the inverse process was also accentuated due to the technological progress of the small and medium-size companies, which received the equivalent of 660000 dollars in the same period from the large companies. ${ }^{22}$ Taking into account other free transfers, it may be seen that technological co-operation among enterprises with different scales of production was highly important.

It should also be pointed out that a very important factor in the technological progress of the medium and small companies was the introduction of systems of quality control and organization of production based on an increasingly widespread use of standardization. This had a variety of effects; it not only improved the quality of the products but also helped to rationalize the production system and encouraged specialization through the vertical integration of manufacturing production. Together with the introduction of advanced technology, it led to a considerable increase in productivity. ${ }^{23}$

An important feature of this process is that while increasing productivity immensely it requires little investment, although the companies must work

\footnotetext{
22 Economic Planning Agency, Economic Survey of Japan, 1969.
}

together. Government guidance and assistance, as well as the understanding and collaboration of the private sector, have been very important.

Finally, this process of industrialization was not wholly spontaneous, since the Government's attitude played a significant role. The Government attached particular importance to its policy for medium and small industries, for which it set up a body within the Ministry of International Trade and Industry. ${ }^{24}$

It should be added that Japanese industrialization has also been affected by the special relationship between companies and workers -a peculiar system of "employment for life", with workers' unions basically organized by enterprise rather than by job or trade as in other countries. Without this system of stable employment, for example, the companies would not have been able to invest heavily in the training of their workers. Furthermore, this form of union organization also made a large contribution to the simultaneous development of the large and the medium and small enterprises without serious labour difficulties, and thus determined other unusual features of Japanese industrialization.

${ }^{23}$ The introduction of standards is also closely linked to quality control in exports of manufactures. The example of sewing machines and other light machinery is well known (see "Export promotion in Japan...", op. cit., chapter IV, and also Asian Productivity Organization, Industrial Standardization in Japan, Tokyo, 1971.)

${ }^{24}$ It would be well worthwhile making an exhaustive assessment of Japanese policy in relation to medium and small enterprises, from the standpoint of the situation of developing countries (see Ministry of International Trade and Industry, Outline of Policy for Smaller Enterprises - Japanese Experience published by the Asian Productivity Organization, Tokyo, 1969.) 


\section{Choice of technology and industries}

As may be seen from the preceding analysis, the absorption of a large amount of labour by the manufacturing industry was largely due to two features which characterized manufacturing development in Japan: the unusual structure of the industry, in which certain subsectors were particularly important, and the coexistence and simultaneous development of companies of different sizes.

This process was not the result of a deliberate policy to choose technology and industries which would directly absorb a high quantity of labour.

Although after the war there was a real and potential labour surplus in Japan, a broad employment policy was not adopted to deal directly with the problem. Instead, various measures of limited scope were adopted, such as the allocation of special funds for the construction of the infrastructure. In addition, no attempt was made to absorb labour through the adoption of labourintensive technology. ${ }^{25}$

\footnotetext{
25 The choice of technology was usually guided by factors other than employment. For example, in its early stages the Japanese motor-vehicle industry adopted various special techniques, such as the use of synthetic plastic dies for moulding bodies. This method is usually used in the manufacture of bodies at the experimental stage, but with a few changes it became economical for a limited production scale of 500 units or less. In addition, for a production scale between 500 and 2000 units per month, simple metal dies were used, while a number of jobs which did not call for great precision continued to be done by hand, such as cutting and bending edges, etc. The methods used in this period were much less capitalintensive than normal methods, and were adopted because the scale of production was small; this was in turn determined by the characteristics of the demand for motor vehicles during that period (see Ministry of International Trade and Industry, official report on technology, 1955).
}

The adaptation of technology imported into Japan should also be analysed. The economic survey of Japan in 1967 notes that significant technological improvements were made in 60 of the 68 products, manufactured with the use of imported technology, whose production had sharply increased. According to the official study on foreign trade in 1967 , over 70 per cent of the imported technology used in the electronic equipment and electrical machinery industries was modified and improved in Japan, and it was precisely thanks to this ability to absorb and improve technology that the electronic industry grew and was oriented towards exports.

However, these improvements and adaptations were generally aimed at increasing productivity, improving the quality of the products and applying imported technology to the manufacture of new products, etc.; it cannot be said that they were directly designed to absorb a larger amount of labour. ${ }^{26}$

What can be said is that in many cases more advanced technology was introduced only in the main production process, without substantially altering the sub-processes (for example, packing, carriage of intermediate products within the factory, manufacture of some components, etc.), which are usually more labour-intensive. It may be argued that this situation obtained not only in individual factories but also in the majority of the industrial branches and in the manufacturing sector in general, since advanced technology was applied

${ }^{26}$ On the other hand, it is not true either, at least in the $1950 \mathrm{~s}$, that advanced technology was introduced to save labour. 
Table 13

JAPAN: INCREASE IN PRODUCTIVITY OF MANUFACTURING, BY SIZE OF ENTERPRISE

(Per cent)

\begin{tabular}{|c|c|c|c|c|}
\hline & \multicolumn{2}{|c|}{$\begin{array}{l}\text { Increase in value added } \\
\text { per worker, } 1962-1970\end{array}$} & \multicolumn{2}{|c|}{$\begin{array}{l}\text { Index of value added } \\
\text { per worker, } 1970 \\
\text { (average for manufac- } \\
\text { turing industry }=100 \text { ) }\end{array}$} \\
\hline & $\begin{array}{l}\text { Plants with } \\
20-299 \\
\text { workers }\end{array}$ & $\begin{array}{l}\text { Plants with } \\
300 \\
\text { workers } \\
\text { or more }\end{array}$ & $\begin{array}{l}\text { Plants with } \\
20.299 \\
\text { workers }\end{array}$ & $\begin{array}{l}\text { Plants with } \\
300 \\
\text { workers } \\
\text { or more }\end{array}$ \\
\hline Total, manufacturing industry $a$ & 13.8 & 13.3 & 100 & 100 \\
\hline Food & 13.3 & 10.7 & 109 & 85 \\
\hline Textiles & 14.1 & 9.2 & 72 & 41 \\
\hline Chemicals and petrochemicals ${ }^{b}$ & 16.0 & 17.3 & 210 & 189 \\
\hline Petroleum and coal products & 17.2 & 14.1 & 202 & 297 \\
\hline Iron and steel & 15.7 & 17.2 & 138 & 109 \\
\hline Non-ferrous metals & 15.1 & 15.3 & 127 & 115 \\
\hline Metal manufactures & 14.4 & 13.2 & 110 & 88 \\
\hline Machinery ex cept electrical & 13.9 & 13.2 & 115 & 102 \\
\hline Electrical machinery & 11.4 & 10.9 & 76 & 90 \\
\hline Transport equipment & 13.3 & 11.2 & 92 & 101 \\
\hline Precision instruments & 12.6 & 12.6 & 83 & 58 \\
\hline $\begin{array}{l}\text { (Value added per worker in } \\
\text { thousands of yen per year) }\end{array}$ & " & & (1 870) & (3 159) \\
\hline
\end{tabular}

Source: Ministry of International Trade and Industry. Kogyo Tokeihyo (Industrial statistics), 1966. aIncluding other manufacturing sub-sectors.

b According to Japan's industrial classification. Does not include rubber manufactures, pulp processing, etc.

in the processes in which the large industries specialized, while the rest of production (various sub-processes such as the manufacture of some components, etc., by smaller companies) continued to use methods which are relatively labourintensive.

In any event, it can hardly be said that choice of technology, or the adaptation of imported technology, was one of the main causes of the absorption of a large amount of labour by the manufacturing sector.

In addition, the general lines of the industrial policy did not aim to stimulate the industries which were apparently more labour-intensive. The Ministry of International Trade and Industry, which 
is responsible for preparing and carrying out industrial policy, points out in this connexion that it was not enough for Japan to centre its activity on textile and miscellaneous industries, the so-called simple industries, which call for a large amount of labour.

"If Japan had specialized in these industries the economy would have come to an almost permanent standstill and the country would not have been able to escape from poverty. Fortunately, however, the objective was to establish highly capital. or technologyintensive industries, such as steel, oil refining, petrochemicals, motor vehicles, aircraft, industrial machinery and the electronics industry, including computers. To encourage these industries was to flout the postulates of short-term economic logic. Nevertheless, from the long-term, dynamic point of view Japan inevitably had to stimulate these industries as quickly as possible in order to be able to provide employment for its 100 million inhabitants and raise the standard of living to a level comparable to that of the United States and the European countries, since those industries are characterized by the high income-elasticity of the demand for their products, their rapid technological progress, their greater side-benefits and a faster growth of labour productivity". ${ }^{27}$

Among the heavy and chemical industries whose installation was encouraged, naturally those grew fastest which had the greatest domestic and external demand. Exports grew fastest in the industries which could take advantage of the favourable factors existing in Japan,

\footnotetext{
${ }^{27}$ Ministry of International Trade and Industry, "Industrial policy of Japan", Japan Reporting, November 1973. This paragraph and the next are based on this report.
}

such as relatively cheap labour and a certain level of technology, to increase their competitive capacity. Thus it was a logical decision for the Ministry of International Trade and Industry to begin applying the above-mentioned policy by promoting exports of light machinery. According to the report quoted, the first step in implementing the promotion policy for heavy and chemical industries consisted in stimulating the light machinery industry, which produced sewing machines, binoculars and cameras. It should be stressed that the policy adopted for these products was to promote simplification, standardization and specialization, and this was a great boon to the development of the machinery industry.

On the other hand, the highly capital-intensive industries whose development was also promoted, such as the steel, petrochemical and chemical industries, received guidelines so that by means of large investment, the introduction of advanced technology and largescale production, their costs would be reduced to the lowest possible levels, comparable to those of the corresponding industries in the European countries and the United States. Exports of these industries also grew rapidly but for very different reasons than in the case of light machinery. The shipbuilding industry possibly falls in between these two types of industries.

A number of industries which used the raw materials produced by the highly capitalintensive industries were able to increase their competitiveness enormously because they were supplied with those materials at prices which were the same as or lower than those of the international market. Besides, these labour-intensive industries enjoy other favourable conditions of their own, such as relatively cheap labour, advanced 
technology and rationalized production. The extraordinary development of the Japanese electronics industry is a case in point, and was also favoured by government policy, through legislation to promote it.

The five-year plans for steel, coal, electricity and ammonium sulphate, and the special measures to promote petrochemicals, synthetic fibres and plastics, enabled industrial inputs to be supplied cheaply to the rest of the manufacturing sector. Furthermore, the legislation to promote the mechanical and electronics industries (adopted in 1956), and exports of light machinery, provided good support for the labour-intensive industries which also use advanced technology, as was pointed out above. The plans for the expansion of the merchant navy are also considered important for the development of the shipbuilding industry.

For some industries the choice of products was also very important, as was, frequently, the creation of their own models adapted to the conditions of demand and production. ${ }^{28}$ For example, the motor vehicles produced in Japan in the early days of the industry had special characteristics: they were more robust on bad roads, capable of carrying bigger loads than the lorries produced in other countries although of a similar size, and more economical in the use of petrol. As an illustration, mention may be made of the large-scale production of three-

\footnotetext{
${ }^{2 B}$ So too, at first, was the need to bear in mind the industrial materials available within the country, because of the shortage of foreign exchange to import foreign raw materials. A case in point is the production of vinylon using domestic raw materials.
}

wheeled vans which were better adapted to the very narrow roads of Japan, and the very small passenger cars with 360 c.c. engines, whose introduction was particularly promoted by the Government.

Exports of motor vehicles from Japan were at first mainly lorries and buses, where it was not necessary to produce on so large a scale as for passenger cars in order to lower costs; it was thus possible to increase Japanese competitiveness with other countries producing the same products. Similar examples may be given from oilier industries. Many products of the electronics industry were thought up and perfected in Japan in accordance with the requitements of domestic and external demands. One well-known example is the application of transistors and diodes -originally invented for industrial use - to domestic appliances. In addition, various articles whose exports grew rapidly, such as watches, cameras and motor-cycles, were originally manufactured for the domestic market and subsequently began to be sold abroad. In other words, many products began to be exported after domestic demand had been satisfied and costs reduced, quality improved and competitiveness raised. Among such products, exports grew more rapidly in the case of those produced in $\mathbf{J}$ apan in more advantageous conditions than in other countries, because of the availability and low cost of various factors of production. That is to say, in Japan there was a process of natural selection of products, with specialization in those products which could compete more easily in foreign markets, although government policy also helped to accentuate the process. Its results were 
reflected very clearly in the structure of Japanese exports. (See tables 5 and 6.) ${ }^{29}$

It may be deduced from the above that in Japan the great relative growth of employment in the manufacturing sector was not necessarily the result of the choice or adaptation of labour-intensive technology or the deliberate choice of labour-intensive industries, but rather the spontaneous growth of the produc tion of articles directly or indirectly employing a relatively large amount of labour.

It should also be recalled that if industrialization had not been vigorously promoted, employment would not have grown to such an extent, as was pointed out by the previously quoted report, ${ }^{30}$ despite the fact that in the short term the heavy and chemical industries did not appear to be very suitable for Japan. Because of their special features, these industries were able to increase their productivity rapidly by means of technological progress, which enabled funds to be saved for greater investment and thus further technological progress to be introduced, which in tum accelerated the rise in productivity. The higher demand for capital goods created by slich investment, and the growth of demand for consumer durables stemming from the greater purchasing power of consumers, stimulated the growth of various new industries. In addition, higher productivity, together with the availability of relatively cheap labour, enabled Japanese industries to acquire the necessary competitiveness for international markets. Rapid industrialization, with emphasis on the heavy and chemical industries, thus created good employment opportunities in the long term.

\section{Development of the agricultural sector and of employment}

Agricultural production in Japan grew considerably after the war, although not as greatly as industrial production. The index of agricultural production rose from 90.4 in 1955 and 85.4 in 1956 $(1960=100)$ to 112 in 1965 , reaching a

\footnotetext{
${ }^{29}$ On the other hand, this process of product selection obviously did not apply to exports of highly capital-intensive industries such as steel, petrochemicals, etc., which generally produce industrial materials with uniform specifications. It may be pointed out, however, that the type of steel which did not call for very advanced technology or high precision was the first to be sold abroad, since the steel produced for export had to meet or exceed the quality standards established in other industrialized countries.

${ }^{30}$ See footnote 27.
}

ceiling of approximately 131 at the end of the $1960 \mathrm{~s}$. Total rice production rose from 9.65 million tons in 1950 to 14.5 million tons in the period 1967-1969 (an annual rate of 2.4 per cent), but subsequently tended to decline as a result of the policy followed to discour * age rice production. The yield per hectare of rice rose from 3.27 .tons in 1950 to 4.5 tons at the end of the 1960s. Between 1958 and 1967 food production also increased (at an annual rate of 6.3 per cent), as did livestock ( 9.7 per cent), vegetables (5.3 per cent) and raw materials for industrial processing such as tea, beets, tobacco and oil-seeds (at an annual rate of 2.7 per cent); on the other hand, there was a considerable fall in the production of wheat and potatoes, which have always 
been relatively unimportant in Japanese agricultural production.

As is well known, agricultural land per person employed in agriculture has always been very limited in Japan. Following the war it even fell slightly with the conversion of agricultural land into industrial and residential zones. The land cultivated per production unit (normally one family) was only 1.2 hectares in 1967, which represented one-tenth of the European average and 1 per cent of the United States average. (See table 14.)
For this reason, immediately after the war it was considered very difficult to mechanize agriculture, since besides the small size of family farms there were other unfavourable factors such as the specific features of rice cultivation (the need to flood paddy fields, etc.) and the geographic nature of the agricultural zones (high percentage of cultivated areas in mountainous zones; cultivation of rice and other products in terraces on the sides of valleys).

Nevertheless, despite these unfavourable factors, considerable progress has

Table 14

SOME AGRICULTURAL INDICATORS OF INDUSTRIALIZED COUNTRIES, 1967

\begin{tabular}{lccc}
\hline & Japan & $\begin{array}{c}\text { European } \\
\text { Economic } \\
\text { Community }\end{array}$ & $\begin{array}{c}\text { United } \\
\text { States }\end{array}$ \\
\cline { 2 - 3 } $\begin{array}{c}\text { Number of persons employed } \\
\text { in agriculture (thousands) }\end{array}$ & 10270 & 11148 & 0.1 \\
$\begin{array}{c}\text { Number of persons employed } \\
\text { for every 10 hectares }\end{array}$ & 14.9 & 1.6 & 120.1 \\
$\begin{array}{c}\text { Average surface area cultivated } \\
\text { per production unit (hectares) }\end{array}$ & 1.2 & 11.5 & 344 \\
\hline
\end{tabular}

Source: Economic Planning Agency, Economic Survey of Japan, 1970. Data based on statistics of the Organization for Economic Co-operation and Development (OECD).

been made in mechanization. Small machinery (such as tractors) was designed to suit the country's conditions. The number of tractors and mechanical cultivators, mostly of less than $10 \mathrm{H.P}$., rose from 90000 in 1955 to nearly 2 million at the end of 1965 and over 3.5 million in 1971. The number of agricultural transport vehicles (vans, etc.) also grew very rapidly, reaching over 1 million in 1972, as did agricuttural machinery: crushers and riceplanting, watering and drying machinery.
It is interesting to study the effect of this process of modernization, and particularly mechanization, on employment in agriculture. The number of rural families remained constant at 6 million in the 1950s and dropped slightly, by about 10 per cent, in the 1960 s. Most important, however, was that at the end of the 1950s there was a sharp drop in the number of families working full time in agriculture and, on the other hand, a rapid rise in the number devoted simultaneously to agriculture and other 
activities. Of this, the greatest rise was in the families whose non-agricultural income was higher than their agricultural income. Thus the number of persons occupied exclusively in agriculture fell from about 14.23 million to 7.87 million between 1955 and 1971. Another important feature is the higher percentage of persons aged 40 or more occupied in agriculture. In $1966,59.3$ per cent of the persons occupied in agriculture were aged 40 or more, and 28.6 per cent 55 or more.

This was due to the fact that in the agricultural zones and surrounding areas non-agricultural job opportunities increased, as did employment in the big cities. In Japan it is increasingly common for the parents to continue working in agriculture while their children are employed in nearby factories and only work in agricultural activities during the busiest period. The growth of employment in rural zones may be attributed both to the growth of local mediumsized and small industries and the decentralization of the large industries which looked for labour in the rural zones, as well as to the expansion of the services sector (commerce, transport, tourism).

This was not really a purely post-war phenomenon, but rather one which had been going on for a long time. An FAO study on agricultural development in Japan $^{31}$ pointed out, for example, that some large industries were installed in rural zones in the initial period of industrialization. These included a wide variety of industries and not merely those dependent on domestic agricultural raw materials, such as the food

\footnotetext{
31 Japan FAO Association, Agricultural Development in Modern Japan, Ogura Takekazu (ed.), Tokyo, 1966.
}

processing and silk winding and spinning industries. These industries unquestionably had a strong impact on employment opportunities. Before 1883, approximately 80 per cent of factories were scattered in rural zones. At that time more than 30 per cent of persons occupied in agriculture had a second job. According to the first agricultural census of 1920,45 per cent of agricultural workers had a second job. The census also indicates that the relatively small industries established in rural or urban zones, which used a large amount of labour, were not inefficient industries artificially trying to rivive traditional, backward methods merely to exploit additional labour; on the contrary, they were mostly highly productive, and represented a refined state of technology suited to the proportion of factors of production which existed in Japan. ${ }^{32}$

The FAo study quoted above also mentions the effect of Japanese rural industrialization. Besides contributing to industrial growth in general, the small industries scattered throughout the rural zones served to bridge the gap between industry and agriculture. On the one hand, they offered complementary employment and income to the agricultural workers, thus relieving the pressure on

${ }^{31}$ According to Ogura Takekazu (ed.), op. cit. the installation of factories in rural zones of Japan at the end of the nineteenth century was primarily influenced by the entrepreneurial spirit of the landowners. The landowners, who appropriated about 50 per cent of the agricultural product by way of rent, part of which was used to pay land taxes, used their net income sensibly, largely devoting it to the improvement, marketing and financing of agricultural production, and also to the establishment of many small industries in rural areas, particularly for the processing of agricultural products, such as oil, flour, paper, alcoholic beverages and spinning and weaving factories. 
the land; on the other, since they were installed in the middle of agricultural communities, they helped to keep down the social costs of industrialization and thus relatively cheap labour was availa- ble. Finally, by familiarizing the rural population with industrial methods they facilitated the promotion of more advanced methods in the agricultural sector.

\section{II \\ China's experience ${ }^{33}$}

In 1949 the economic situation in China was most unfavourable. Heavy industry was very limited, with steel production not exceeding 1 million tons a year; machinery industries were virtually non-existent; the railway network was only about 12000 miles in length. A few electric power stations supplied the big cities, but in rural areas electricity was practically unknown. Around 80 per cent of the economically active popula tion was engaged in agriculture.

The industrial base and infrastructure in China were smaller that year than in Russia in 1914 and in India when it gained its independence.

For years, moreover, civil wars, foreign armed invasions, floods and other natural disasters had seriously impaired the production base and infrastructure.

It should also be noted that the area of arable land per person engaged in agriculture was very small and, according to estimates, smaller even than in Japan.

Up to the middle of the $1950 \mathrm{~s}$, the main feature of China's economic policy was industrial development, special importance being given to heavy industry and central planning. This policy,

\footnotetext{
${ }^{33}$ For the analysis given in this chapter use was made almost exclusively of official information from China and data supplied by officials of the Japanese Government or its agencies.
}

which is similar to that adopted by other socialist countries, was later abandoned and an attempt was made to seek its own lines of development in the light of the conditions prevailing in China, such as the predominance of the agricultural sector and its vast population.

This new economic development policy in known as the policy of "walking on two legs", or "the simultaneous development of industry and agriculture". It was launched in 1958 with the Great Leap Forward campaign. $^{34}$ Subsequently, these principles

\footnotetext{
${ }^{34}$ Although this policy was not implemented until 1958, its roots go farther back. For example, in 1955 the Ministry of Planning said: "Our task is to arrive at a proper distribution of investments anong big, medium and small enterprises in the course of industrial construction, and to effect co-ordination and mutual support in the construction of these various enterprises, so as to guarantee not only construction of the necessary priority projects, but also quick returns from investments. Many medium and small scale enterptises can be built in a short time, bringing quick returns on investment and adding to our productive capacity. They not only play an important role in increasing supplies of industrial products and supporting agricultural production but they also constitute an indispensable factor in increasing accumulation of funds for supporting and assisting construction of big priority projects" (Li Fu-chun, Report on the First Five-Year Plan, Peking, 1955, cited by Wheelwright and McFarlane, in The Chinese Road to Socialism, London, 1970).
} 
changed in line with a general development policy with "agriculture as the foundation and industry as the focus". Other objectives were to "develop large, medium and small industries simultaneously" and to "aim at an overall development of forestry, cattle, fishing, and subsidiary industries around the axis of grain production". These policies were fully implemented towards the end of the 1960s.

China's policy pursued the simultaneous development of agriculture and industry (heavy and light industry; central and local industries; modern and traditional technology). It took this form in view of the fact that the country had over 700 million inhabitants living mainly in rural areas.

It is important to know how this policy solved various development problems in an economy characterized by a shortage of production resources for so large a population. Before evaluating this policy, it may be useful to give a brief summary of its results.

\section{Characteristics of economic development and rural industrialization}

The first stage of implementation of the aforementioned policy was the period of the Great Leap Forward campaign (in the late 1950s), which fostered the construction of small-scale industrial plants in rural areas throughout the country. These plants were basically designed to provide the inputs and articles required for the execution of various agricultural infrastructure projects, such as irrigation, reforestation, road construction, etc.

The main projects were the construction and installation of hydroelectric plants, agricultural machinery and implement industries, fertilizer industries, and industries for processing agricultural products. The next step was to develop the coal mines, the production of steel, cement and other inputs, and simple machine-tool industries. All these enterprises were small or medium-sized, they were established in the provinces and supplied the necessary elements for the above-mentioned rural industries.

The result was that the average number of plants in each province increased from two to thirty between the years 1957 and 1959. An article published in 1960 states that in the Great Leap Forward period 3 million factories were installed in China, of which 200000 survived as firmly established plants. ${ }^{35}$

In 1958-1959, a large number of small blast furnaces, with a capacity of up to 100 cubic metres each and a total capacity of 43000 cubic metres, were constructed. Some medium blast furnaces with a total capacity of 24000 cubic metres were also built, and their production, which was of good quality, amounted to 50 per cent of the total pig iron output (the pig iron output per cubic metre of fumace column in 1959 was 0.85 tons in the small furnaces and 1.49 tons in the big furnaces). In the steel industry, small and medium converters, taking less than 3 tons, were widely used, and produced over 3 million of the

${ }^{35}$ According to an article by Shen Li-jen published in Chingchi yenchin, 1960, No 3, cited by R. Kojima, "Development of the ideas of the Great Leap Forward under the Cultural Revolution", The Developing Economies, December 1971. 
11 to 12 million tons of China's output of steel in 1958. In coal mining, medium and small mines produced 40 per cent of total output in 1958 and $1959 ; 81$ per cent of all coal was mined by modem methods, and of this about 24 per cent was obtained by modernized small-scale mining. ${ }^{36}$ Over 10000 plants for the extraction of oil from shale, with an annual capacity of less than 100 tons each (as well as $\mathbf{1 0 0}$ medium plants and 500 medium refineries) were built, their total capacity amounting to 1.2 million tons or approximately 80 per cent of domestic output in 1958. In addition, 2000 small acid and soda plants had been established in rural areas by May $1959 .^{37}$

It is important to note that simultaneously with the establishment and expansion of small and medium-sized local industries, some large-scale industries were established. The large-scale industries established in the period covered by the First Five-Year Plan continued to be the main suppliers of iron, steel, heavy machinery, machinetools and power. Although many rural communes constructed small power plants, large hydroelectric stations such as those at Tankiangkou $(900000 \mathrm{KW})$, Hsinan $(652000 \mathrm{kw})$ and Kwangsi $(210000 \mathrm{KW})$ started operating in 1958-1959. Some large thermal units were also constructed, as for instance the $225000 \mathrm{~kW}$ station at Tsinan. The development of large-scale steel plants

\footnotetext{
${ }^{36} \mathrm{~S}$. Adler, statement made at the Statistical Institute of India, New Delhi, on 26 December 1959, cited by Wheelwright and McFarlane, op. cit.

${ }^{37}$ For various other examples of the establishment of small and medium-sized industries, see Wheelwright and McFarlane, op. cit.
}

also dates from this period: plants with an annual capacity of 700000 tons were established at Shenyang and Dairen. ${ }^{38}$

A similar process took place in the late $1960 \mathrm{~s}$, but enriched by the experience gained in the Great Leap Forward and ensuing years.

The progress of rural industrialization in the late $1960 \mathrm{~s}$ is considered to be unprecedented in China. Before the end of 1970, agricultural machinery plants had been established in over 90 per cent of the 2300 provinces of China, while small steel plants were constructed in 300 provinces and towns. ${ }^{39}$ In the same period, local fertilizer plants with a production capacity of $2000-3000$ tons annually were established in provinces throughout the country. Their combined output represented 43 per cent of China's total production in 1970 and approximately 60 per cent in 1971.40 The 1966 figure had been 15 per cent. (See table 15.)

Similarly, it is estimated that the production of small plants in the provinces represented between 12 and 17 per cent of total steel and electric power output in 1970. The corresponding proportion for cement, iron ore and coal was 30 to 40 per cent. ${ }^{41}$ As early as 1966, local production of agricultural machinery and implements represented two-thirds of domestic output, and by

\footnotetext{
${ }^{38}$ Wheelwright and McFarlane, op. cit.

${ }^{39}$ Jenmin Jihpao, 27 December 1970 , cited by R. Kojima, op, cit.
}

${ }^{40}$ Official figures given by the Ministry of International Trade and Industry in an article in Japanese on the prospects regarding trade relations between Japan and China, published in Boeki Seisaku (Trade Policy), September 1972.

${ }^{1}$ Ibid. 
Table 15

CHINA: RURAL INDUSTRIAL DEVELOPMENT IN RELATION TO TOT AL INDUSTRIALIZA TIONa

\begin{tabular}{|c|c|c|c|c|c|c|c|c|c|}
\hline \multirow{2}{*}{ Year } & \multicolumn{3}{|c|}{$\begin{array}{l}\text { Power generation } \\
\text { (thousands of } K W \text { ) }\end{array}$} & \multicolumn{3}{|c|}{$\begin{array}{l}\text { Steel production } \\
\text { (thousands of tons) }\end{array}$} & \multicolumn{3}{|c|}{$\begin{array}{l}\text { Fertlizer production } \\
\text { (thousands of tons) }\end{array}$} \\
\hline & $\begin{array}{c}\text { Total for } \\
\text { the whole } \\
\text { country }\end{array}$ & $\begin{array}{c}\text { Small } \\
\text { noral } \\
\text { plants }\end{array}$ & $\begin{array}{c}\text { Percent- } \\
\text { age of } \\
\text { total }\end{array}$ & $\begin{array}{c}\text { Total for } \\
\text { the whole } \\
\text { country }\end{array}$ & $\begin{array}{l}\text { Small } \\
\text { rural } \\
\text { plants }\end{array}$ & $\begin{array}{c}\text { Percent- } \\
\text { age of } \\
\text { total }\end{array}$ & $\begin{array}{c}\text { Total for } \\
\text { the whole } \\
\text { country }\end{array}$ & $\begin{array}{l}\text { Small } \\
\text { rural } \\
\text { plants }\end{array}$ & $\begin{array}{c}\text { Percent } \\
\text { age of } \\
\text { total }\end{array}$ \\
\hline 1953 & 2350 & 5 & 0.2 & 1873 & 100 & 5.3 & 226 & - & - \\
\hline 1957 & 4454 & 20 & 0.4 & 5604 & 163 & 2.9 & 630 & - & - \\
\hline 1959 & 9834 & 400 & 4.0 & 13350 & 4720 & 35.5 & 1330 & - & - \\
\hline 1971 & $12800^{b}$ & $1500^{\mathrm{b}}$ & $11.8^{b}$ & 21000 & 3500 & 16.6 & 16800 & 10000 & 60.0 \\
\hline
\end{tabular}

Sources: 1953-1970: Reeitsu Kojima, "Development of the ideas of the Great Leap Forward after the Cultural Revolution", The Developing Economies, December 1971; 1971: article by the Ministry of International Trade and Industry of Japan on prospects regarding trade relations between Japan and China, published in Boeki Seisaku (Trade Policy), September 1972.

aEstimates.

b1970.

the end of the 1960s the proportion was estimated at iround three-quarters. ${ }^{42}$

This rural industrialization process took place at two levels: the provinces and the communes. At the provincial level, in addition to the agricultural machinery, fertilizer and steel industries already referred to, plants for the production of small electric generators, other electrical machinery and appliances, simple machine-tools, etc. were also established. The rural communes, on the other hand, constructed and operated repair shops for agricultural machinery and implements, and also for transport equipment (lorries, etc.); iron and coal mines; plants producing yarn, insecticides, bricks, plants for processing agricultural products, such as rice and

${ }^{42}$ R. Kojima, op. cit. wheat mills; and facilities for the extraction of oil, sugar refining, prepara tion of noodles from potato flour, production of wines and liquors, etc. Small 20-30 KW hydroelectric plants capable of supplying from one to three communes were also built in nural areas.

The industries established in the provinces constitute the nucleus of rural inalustry. The integrated machinery plants in the provinces are responsible for supplying the smaller plants in the communes with equipment and other articles, besides producing dynamos and other electrical products. Lastly, the articles produced in special districts or the capital cities of various provinces include high-quality machine-tools, large tractors, and machinery and equipment for fertilizer and steel plants.

This system of stratification of rural industrial development is an important feature of the 1960s if compared with 
Table 16

CHINA: PRODUCTION OF CERBALS

(Three-year averages)

\begin{tabular}{|c|c|c|c|}
\hline Three-year periods & $\begin{array}{c}\text { Production } \\
\text { of cerestis } \\
\text { (millions of tons) }\end{array}$ & $\begin{array}{c}\text { Population at } \\
\text { end of three-year } \\
\text { period b } \\
\text { (millions of } \\
\text { inhabitants) }\end{array}$ & $\begin{array}{c}\text { Production per } \\
\text { inhobitant } \\
\text { (kilograms) }\end{array}$ \\
\hline $1952-1954$ & 157.4 & 581.9 & 216.4 \\
\hline $1957-1959$ & 197.8 & 648.4 & 244.0 \\
\hline $1960-1962$ & 184.8 & 692.0 & 213.6 \\
\hline $1963 \cdot 1965$ & 232.2 & 735.7 & 252.5 \\
\hline $1971-1973$ & 250.0 & 879.1 & 227.5 \\
\hline $\begin{array}{l}1952-1973 \\
\text { (cumulative annual } \\
\text { growth rate) }\end{array}$ & 2.5 & 2.2 & 0.3 \\
\hline
\end{tabular}

Sources: S. Swamy, "Economic growth in Ching and India", Economic Development and Cultural Change, July, 1973; Ministry of International Trade and Industry of Japan, Report on foreign trade, 1974, 1975.

a Official figures and estimates.

bEstimate obtained by extrapolation of the 1953 figures at 2.2 per cent annually.

Table 17

CHINA: MANUFACTURING OUTPUT

(Index: $1956=100$ )

\begin{tabular}{lcc}
\hline Years & Official series & S. Swamy series \\
\hline $1952-1954$ & 62.0 & 66.5 \\
$1957-1959$ & 184.8 & 145.5 \\
$1963-1965$ & 210.1 & 161.4 \\
1970 & 300.8 & 259.3 \\
$1952-1970$ (cumulative annual growth rate) & 6.7 & 5.8 \\
\hline
\end{tabular}

Sources: S. Swamy, op. cft. 
the Great Leap Forward period, when no significance was attached to this aspect.

Another salient feature of rural industrialization in the $1960 \mathrm{~s}$ is that importance was given to the supply of modern inputs for agriculture. In the 1950 s this goal was none too clear; but in the 1960s, and especially in the second half of the decade, rural industrialization was carried out in line with the conditions and the growth of demand in the agricultural sector.

Official data show that in the last 10 years the harvests have been satisfactory; production of cereals amounted to 240 million tons in 1970 and 250 million in 1971. This is the result of two factors: the increase in both modern and traditional inputs due to rural industrialization, and the modernization and improvement of the infrastructure (see table 16).

Furthermore, manufacturing output has increased considerably in recent years. An increase of around 20 per cent annually was obtained in 1969 and 1970 , and over 10 per cent in $1971 .^{43}$ It is estimated that in the last few years the Chinese economy has maintained a cumulative annual increase of over 10 per cent in the gross national product. ${ }^{44}$ (See tables 17 and 18.)

These figures would seem to indicate that rural industrialization was one of the main instruments of China's economic development in the 1960s. The relationship between rural industrialization and the modemization of agriculture is analysed below.

\section{Modernization of the agricultural sector and the employment problem}

The area of cultivated land in China is small in relation to the number of inhabitants engaged in agriculture. Only about 12 per cent of the land is cultivated (including the fruit-growing areas), while 80 per cent of the population is engaged in these activities.

How, then, has China modernized its agriculture in the last 20 years?

It is well known that following a transitory period of co-operatives, agricultural communes were organized at the end of 1958. Almost all the rural families joined 70000 communes, each of which comprised between 5000 and 50000 families. $^{45}$ The organization of communes took place at the same time as the campaigns to construct large-scale irrigation works and infrastructure.

In 1958, China established general guidelines for the systematic modernization of agricultural production tech- niques, which are known as "the eight basic principles of agriculture": deep cultivation and soil improvement, use of fertilizers, expansion of irrigation, seed improvement, intensive cultivation, eradication of agricultural pests and diseases, soil conservation, and modernization of agricultural implements.

As regards mechanization, attempts were made initially to improve and extend the use of traditional agricultural

\footnotetext{
${ }^{43}$ Yoshio Akino, "Present and future situation of the Chinese economy", ESP (in Japanese), July 1972.

4t Ibid.

45 At the outset, the number of communes was 26578 , with the participation of 123 million families and an average of 4637 families per commune (in 1958).
} 
Table 18

CHINA: OUTPUT OF MAIN INDUSTRIAL, PRODUCTS

(Three-year averages)

\begin{tabular}{|c|c|c|c|c|c|c|c|c|c|c|}
\hline \multirow[t]{2}{*}{ Years } & \multirow{2}{*}{$\begin{array}{l}\text { Electrl } \\
\text { city } \\
\text { (billions } \\
\text { of } K W H)\end{array}$} & Coal & $\begin{array}{l}\text { Crude } \\
\text { petro } \\
\text { leum }\end{array}$ & $\begin{array}{l}\text { Raw } \\
\text { steel }\end{array}$ & $\begin{array}{l}\text { Chemical } \\
\text { ferti- } \\
\text { lizers }\end{array}$ & Cement & Paper & Sugar & \multirow{2}{*}{$\begin{array}{l}\text { Wood } \\
\text { (millions } \\
\text { of cubic } \\
\text { metresi) } \\
\end{array}$} & \multirow{2}{*}{$\begin{array}{l}\text { Cotton } \\
\text { textiles } \\
\text { (billions } \\
\text { of metres }\end{array}$} \\
\hline & & \multicolumn{7}{|c|}{ (millions of tons) } & & \\
\hline $\begin{array}{l}1960 \\
1962\end{array}$ & 38.3 & 292 & 4,8 & 12 & 2.9 & 8.5 & 2.6 & 0.9 & 34 & 4.5 \\
\hline $\begin{array}{l}1963 \\
1965\end{array}$ & 34.7 & 230 & 7.0 & 10 & 4.3 & 8.0 & 2.9 & 1.1 & 31 & 4.7 \\
\hline $\begin{array}{l}1966- \\
1968\end{array}$ & 42.7 & 213 & 10.3 & 11 & 4.8 & 11.0 & 1.7 & 1.7 & 36 & 5.0 \\
\hline 1970 & 60 & 255 & 20.0 & 18 & 14.0 & 13.5 & 2.5 & 1.7 & 38 & 8.5 \\
\hline 1971 & 71 & 275 & 25.6 & 21 & 16.8 & 16.5 & & & & \\
\hline 1973 & & & 50.0 & 25 & 25.0 & & & & & \\
\hline $\begin{array}{l}1960 \\
1971 \\
\text { (cumu- } \\
\text { lative } \\
\text { annual } \\
\text { growth } \\
\text { rate) }\end{array}$ & 6.4 & -0.6 & 18.2 & 5.8 & 19.2 & $6.9^{\mathrm{a}}$ & $\cdot 0.4^{\mathrm{B}}$ & $6.6^{\mathrm{a}}$ & $1.1^{2}$ & $6.6^{\mathrm{a}}$ \\
\hline
\end{tabular}

Sources: 1960-1970: S. Swamy, op. cit.; Ministry of International Trade and Industry of Japan, various publications.

a $1960-1970$.

implements and promote their production in rural areas. This process was limited at first (1958 and ensuing years) to the improvement of hand tools, since they could easily be produced by local industries. This policy contrasted with that of the previous period when unsuccessful attempts were made to foster the production of animal-drawn agricultural implements or machinery, which at that time were manufactured by plants in large or medium-sized cities.

The period 1958-1960 also witnessed the large-scale introduction of various types of irrigation equipment, primitive transport equipment for agriculture, and implements for more intensive cultivation such as ploughs for deep cultivation and machinery for closer planting.

The introduction of agricultural machinery is a complicated process which requires time and experience, but after a period of trial and error the more advanced stage of mechanization of agricultural production began in the 1960s. The total power incorporated in agriculture (including all types of tractors and pumps) rose from 0.6-0.9 million HP in the late 1950s, to 5.3 million in 1962-1964 (see table 19). The 
number of tractors doubled in five years (1965-1970) to a total of 300000 (with an average of $15 \mathrm{HP}$ ). The use of machinery for harvesting, processing agricultural products, threshing, draining and irrigation also increased. ${ }^{46}$

There was an increase, too, in the use of fertilizers: the total quantity used in agriculture rose from less than 1 million metric tons in 1954 to around 2 million in $1957,3.5$ million at the beginning of the 1960s, and 6 million in 1964. In 1971 it is estimated to have reached at least 20 million tons. ${ }^{47}$ This was largely due to the increase in the production of small and medium plants established in rural areas.

Since the area of cultivated land in China is very small in relation to the number of persons engaged in agriculture, it may well be asked how it was possible to employ the labour force productively in this modernization process. It might be thought that mechanization and other measures would lead to a surplus supply of manpower.

This point was also raised at first in China itself. In some articles published in an official periodical ${ }^{48}$ it was pointed

\footnotetext{
${ }^{46}$ Hideo Yamamoto, "The agricultural mechanization process in China", ESP (in Japanese), 1972.

4716.8 million tons produced in China plus 2.8 million tons imported. See table 18 and Ministry of International Trade and Industry, Official report on foreign trade (in Japanese), 1972.
}

48 For example, an article in the periodical Planned Economy (in Chinese), April 1954, cited by Reeitsu Kojima in "The agricultural machinery and implements industry in the development of the national autonomous economy", Ajia Keizai (in Japanese), September 1966 . out that there was a limit to the rapid mechanization of agriculture, in view not only of the lack of petroleum but also of the fact that although mechanization increases productivity per worker it does not raise the yield per hectare; therefore, in areas with plentiful manpower it would merely lead to a surplus of labour.

A solution was found to these problems, however. The labour saved by mechanization and modernization, and also the natural increase in manpower, was employed in various activities designed to step up agricultural production: (a) intensive cultivation, especially deeper cultivation of the soil and multiple crops (two or three per year); (b) the construction of irrigation works and the development of new agricultural land; and (c) rural industries.

As regards the first point, a sound indicator is the index of multiple crops, which rose from 134 in 1952 to 143.1 in 1964. It must be considered, moreover, that the area sown increased from 112.3 million hectares in 1952 to 128.7 million in $1964^{49}$ (see table 19).

The important factor in rural industrialization is the close relationship between agriculture and the industries established in rural areas. In fact, many of the industries form part of the agricultural communes. The workers in rural industries are mostly peasants who have received some training. Tractor drivers and other technical specialists were also chosen from among the rural workers in the respective communes, as being the persons most familiar with the conditions prevailing in the area. Tempo-

\footnotetext{
${ }^{* 9}$ Reeitsu Kojima, "Reappraisal of the Great Leap Forward policy with special reference to the industrialization of the rural economy", Alta Keizat (in Japanese), December 1967.
} 
Table 19

CAINA: INPUTS FOR AGRICULTURE

(Three-year averages)

\begin{tabular}{lcccc}
\hline Three-year period & $\begin{array}{c}\text { Area sown } \\
\text { (millions of } \\
\text { hectares) }\end{array}$ & $\begin{array}{c}\text { Use of } \\
\text { fertilizers } \\
\text { (milions } \\
\text { of tonsja }\end{array}$ & $\begin{array}{c}\text { Machinery } \\
\text { (millions } \\
\text { of HF) }\end{array}$ & $\begin{array}{c}\text { Index of } \\
\text { multiple } \\
\text { crops }\end{array}$ \\
\hline $1952-1954$ & 114.3 & 0.57 & 0.05 & 135 \\
$1957-1959$ & 120.8 & 2.53 & 0.72 & 141 \\
$1962-1964$ & 127.7 & 5.11 & 5.27 & 140 \\
$\begin{array}{l}1952-1964 \text { (cumulative } \\
\text { annual growth rate) }\end{array}$ & 1.1 & 24.5 & 59.3 & 0.4 \\
\hline
\end{tabular}

Source: S. Swamy, op. cit.

${ }^{a}$ Including imports and production of $\mathrm{N}_{3} \mathrm{P}_{2} \mathrm{O}_{5}$ and $\mathrm{K}_{2} \mathrm{O}$.

bIncluding all types of pumps and tractors (according to official data, the figure for 1970 is twice the 1965 figure, 4.5 million HP of which represents tractors).

Table 20

CHINA AND INDIA: PRODUCTION, AREA SOWN AND YIELD PER HECTARE, BY PRODUCTS

\begin{tabular}{|c|c|c|c|c|c|}
\hline & \multirow{2}{*}{ Period } & \multicolumn{3}{|c|}{ China } & \multirow{2}{*}{ India } \\
\hline & & Rice & Wheat & Total $^{\mathrm{a}}$ & \\
\hline \multirow[t]{3}{*}{$\begin{array}{l}\text { Production of processed cereals } \\
\text { (milions of tons) }\end{array}$} & $1952-1956$ & 53.4 & 18.3 & 136.3 & 63.9 \\
\hline & 1957.1959 & 65.6 & 21.3 & 160.9 & 71.2 \\
\hline & $1961-1965$ & 70.3 & 21.1 & 175.4 & 83.5 \\
\hline \multirow[t]{3}{*}{$\begin{array}{l}\text { Area sown } \\
\text { (millions of hectares) }\end{array}$} & $1952-1956$ & 30.0 & 26.3 & 116.2 & 105.8 \\
\hline & $1957-1959$ & 32.5 & 27.1 & 120.8 & 112.2 \\
\hline & $1961-1965$ & 33.2 & 25.1 & 126.3 & 117.0 \\
\hline \multirow[t]{3}{*}{$\begin{array}{l}\text { Yield } \\
\text { (tons per hectare) }\end{array}$} & 1952.1956 & 1.8 & 0.7 & 1.2 & 0.6 \\
\hline & $1957-1959$ & 2.0 & 0.8 & 1.3 & 0.6 \\
\hline & $1961-1965$ & 2.1 & 0.8 & 1.4 & 0.7 \\
\hline
\end{tabular}

Source: S. Swamy, ap. cit.

${ }^{a}$ Including other cereals and potatoes (value of production equivalent to cereals).

bincluding rice, wheat and other cereals, and potatoes. 
rarily unemployed manpower was also used in certain seasons of the year.

Moreover, most of these industries were established on the initiative of the nural workers, with funds set aside by the communes, and they themselves constructed the plants.

Indeed, in certain periods - particularly during the Great Leap Forwardthe labour engaged in non-agricultural activities (infrastructural works, construction and operation of rural industries) increased so rapidly that it affected agricultural production. However, this process enabled the basic problem to be visualized more clearly, since the relative shortage of labour in agriculture for several years brought into focus the need to increase productivity in order to keep manpower available for other activities designed to improve the performance of agriculture. For this reason, the rural industries established in the 1960 s were definitely geared to the production of inputs and capital goods for agriculture.

Thus, manpower engaged in rural industries increased rapidly and accounted for an estimated 15 per cent of the total labour force in rural areas by the end of the $1960 \mathrm{~s}^{\text {so }}$ This contrasts with the situation in the 1950s when manpower engaged in activities other than agriculture was not more than 3.5 per cent. At the time, this percentage was considered excessive ${ }^{51}$ and, in actual fact, agricultural production stagnated. In other words, with the productivity increase in agriculture ${ }^{52}$ it was possible to absorb an increasing number of rural workers in rural industries without undermining agricultural production, and these industries in turn supplied inputs and goods for further improving agricultural productivity.

In certain communes, moreover, the proportion of the labour force engaged in industry is even higher, i.e., up to over 20 per cent, while the value of manufacturing output is approximately one-third of the total value of production (agricultural and industrial) ${ }^{53}$

Assuming that the national average proportion was 15 per cent, the total number of workers engaged in rural industries would be 30 million. This is -much higher than the number of workers engaged in manufacturing industry, which in 1965 was estimated at 13.7 to 14 million. ${ }^{54}$

\section{Some characteristics of technological development}

Technological development in China has passed through various characteristic stages and is in keeping with the policy of "walking on two legs".

One well-known experiment promoted early in 1958 was the production of iron on a very small scale in rural areas. Although the Government had to

\footnotetext{
so Masahisa Sugenuma, Revolution and economy of the 700 million (in Japanese), 1973.
}

rectify the excessive scope of the campaign owing to the low quality of the product, heavy cost of transport,

51 According to an article published in an official periodical (1961) cited by R. Kojima, "Reappraisal ...", op. cit.

52 There are no data availabie on the increase in productivity per worker; for the increase in yield per hectare, however, see table 20. op. cit.

\$3 H. Yamamoto, "The agricultural...", ${ }^{54}$ ESP, July 1972. 
etc. $^{55}$ the campaign itself, according to many observers, had a strong educational impact on the rural workers, who had virtually no scientific or technical knowledge. 56

The blast fumaces, of 3 to 100 cubic metres capacity, could be built fairly rapidly ( 4 to 5 months on average) without need of advanced technology or highly skilled manpower. The iron produced, though not of good quality, was used for the production of agricultural implements and for the infrastructural works that were being actively constructed in that period. In the light of this experience, the production of iron and steel was subsequently organized on a more rational basis in rural areas, taking the quality, cost and other factors duly into account. Some techniques were also perfected. For example, an important factor in the production of iron is the ability to increase the temperature of the blast furnace, for which an efficient air-blowing device is

\footnotetext{
5some authors point out that the small-scale production of iron in the countryside began early in 1958, before the Great Leap Forward policy, and to consider the small-scale blast furnaces established at that time as part of the result of rural industrialization therefore leads to erroneous conclusions, They contend that the rational development of small and medium-scale blast furnaces and converters during the rural industrialization campaign in the Great Leap Forward period, and the expansion of the chemical and machinery industries and other similar activities should be clearly distinguished from the campaign for the very small-scale production of iron ("backyard campaign"), which was short-lived (see Wheelwright and McFarlane, op. cit.).

${ }^{56}$ Masumi Sato, "Technological development in China and its characteristics", ESP (in Japanese), July 1972; Wheelwright and McFarlane, op. cit., etc. R. Kojima, "Reappraisal...", op. cit., estimates that over 100 million peasants took part in the campaign.
}

required. Following the experimental period, electricity-powered air-blowers were introduced. ${ }^{57}$ Although the steelmanufacturing process developed at the time was not a very modern or large-scale method, neither did it represent a revival of that used, say, in the period of the industrial revolution in the European countries, since it included various technological advances. ${ }^{58}$

The fertilizer plants established in rural areas also operated on a small scale and were intended to supply a limited area. The significant advantage enjoyed by the small and medium-scale ammonium sulphate plants was that the rural industries had attained a technological level which enabled them to construct high-pressure towers of adequate size and manufacture the high-pressure compressors for them. ${ }^{59}$ In other words, their construction involved less skilled manpower than was required in largescale plants. Moreover, in addition to ammonium sulphate, the local fertilizer plants produced ammonium bicarbonate and ammonium nitrate, the manufacturing process of which is much simpler and more suited to small-scale production. Although these products cannot be stored for long periods or carried long distances, the small plants were not affected by such difficulties since they only supplied a limited area.

\footnotetext{
57 M. Sato, op. cit.

${ }^{58}$ In this respect, some authors considered the small-scale iron and steel production technology as a case of "intermediate technology". The size of around 550 cubic metres is similar to that of the blast furnaces used in Europe in the first half of the nineteenth century.

59 The internal diameter of the towers is estimated to be about $300-450 \mathrm{~mm}$ and their height $3000-4000 \mathrm{~mm}$, which is very small compared with the towers of large-scale plants.
} 
Much the same may be said about the construction of hydroelectric plants. Instead of a large number of small plants, a smaller number of large-scale plants could perhaps have been built; but their construction would have involved more time and labour, and a considerable concentration of funds, building materials and other inputs -cables, machinery - in addition to manpower. In contrast, for the construction of small plants in rural areas use was made of the manpower available locally, ${ }^{60}$ and the short period of construction permitted the rapid supply of electric energy in the area, with favourable short-term results.

The most important products of the agricultural machinery industry are tractors. At first, large tractors were introduced, but later the industry prepared its own designs for small 10-20 HP tractors. The $15 \mathrm{HP}$ tractor increases the labour productivity of cultivation approximately 13 times. Obviously, if large tractors are used the increase in productivity is greater, but the construction of plants for the production of large tractors requires a longer time, a higher level of precision engineering, more resources, etc.

Concurrently with the gradual development of local industries with intensive use of labour and a technology suited to the conditions found in rural areas, various industries made great efforts to introduce advanced modern techniques and to develop a technology of their own.

The electronics industry is one of those in which most technological

\footnotetext{
60Peasants already had experience of the mobilization of resources for large-scale projects, such as the construction of irrigation dams, reforestation, soil improvement, etc, which were carried out before and during the Great Leap Forward period.
}

progress was made. In a detailed study by a Japanese specialist, ${ }^{61}$ the conclusion was reached that the level of technology of this industry had risen so rapidly in China that by the end of the 1970s the technological lag behind Japan was only 5 to 7 years, whereas at the beginning of the First Five-Year Plan it was over 15 years. The use of transistors dates in China from 1963, some eight years later than in Japan, but it spread very rapidly. The number of plants in the electronics industry in China increased 20-fold between 1965 and 1970 , and the production of semi-conductors in Peking doubled over the period 1968-1969. ${ }^{62}$ The use of silicon transistors began to be fairly widespread in the late 1960 s. Thanks to the considerable capacity of China's electronics industry to design its own models, the mid-1960s witnessed the design and production in China of various elcctronic instruments, including electronic microscopes with a magnifying capacity of 200000 , first produced in 1965 and comparable with those produced in Europe or the United States.

As regards computers, a machine using valves was produced on an

${ }^{61}$ Masumi Sato, "Technological development in China from the angle of the electronics industry", Ajia Keizai (in Japanese), December 1971.

${ }^{62}$ The development of the electronics industry in China in the 1960 s was also due to the technological progress in industrial inputs for this industry as from 1963-1964. In the 1950 s the delay in the production of various inputs -including cold-rolled silicon steel, magnetic steel alloy and plastic insulating materials - was one of the bottlenecks holding back the advance of this industry. Significant progress was reported in the production of silicon steel in 1963-1964, and in the use of plastic materials in 1964-1965. High-purity germanium was produced in China in 1963 , thus permitting the wide use of transistors and diodes. 
experimental basis as early as 1959 . Transistorized computers were produced in 1967, and large computers by the end of the 1960s. At the same time, the technique for the use of computers (software) was developed. Computers are currently used in designing bridges and large dams, in oil exploration and refining activities, for meteorological calculations and for many other purposes. A good indicator of their use was the placing in orbit of small satellites the control of which requires the use of medium or large computers.

Significant technological progress has also been made in the machinery industry, particularly the production of machine-tools. By 1965, machines had been manufactured for cutting spiral bevel gearing, which is indispensable for the production of high-speed gear drives. Subsequently, the Chinese industry was able to produce optical drills. Both these machines are considered to be good indicators of the technological level attained. Other achievements of note are the introduction of numerical control in machine-tools. In 1968 a turret lathe with programmed numerical control was produced, in 1970 a large lathe and a large four-size milling machine, likewise with numerical control, and in 1971 a non-round gear-cutting machine, also with numerical control. In the metals industry, the 12000 ton forging press was an important landmark since it permitted the production of reaction towers for chemical plants, atomic energy equipment, shafts for electric power generating equipment, etc.

In the production of steel, a converter with liquid oxygen injection (LD converter) was put into operation in 1967 , although most of the steel is still produced in Siemens-Martin furnaces. Automatic processes based on Chinese designs have been introduced. There has also been significant progress in the production of regular low-alloy steel, particularly as regards variety and quality. A complete petrochemical plant was recently designed and constructed. Advances are also known to have been made in other industries, such as shipyards, oil refineries and textile machinery.

Lastly, mention should be made of the fact that even in non-rural Chinese industry fairly labour-intensive methods were used. In the electronics industry, for example, the scale of production per establishment is generally considerably lower than in the corresponding industries in more industrialized countries. This occurs not only in assembly plants but also in industries producing industrial inputs and machinery. ${ }^{63}$

To sum up, China has striven to attain a high level of technology by using modern techniques and at the same time promoting the development of its own technology, and it has adopted production methods suited to its raw material and manpower resources. Particularly notable in this respect are the results obtained through mural industrialization. ${ }^{64}$

\footnotetext{
${ }^{63}$ For example, silicon semi-conductors are produced mainly in small plants which do not enjoy the same conditions as those found in industrialized countries, where a strict system of air-conditioning and waste disposal is used, as well as fully automatic processing in the reducing furnaces. In China, the small plants try to keep themselves hermetically sealed by means of some primitive arrangement in the windows and use a manual system in the reducing furnace, with the simple method of extracting hydrogen gas from liquid ammonia (see M. Sato, "Technological development in China...",op. cit.).

${ }^{64}$ This simultaneous technological progress was also evident in other sectors. An illustrative exanple is medicine, which developed the ancient system of acupuncture, homeopathy, etc. side by side with Western medicine.
} 


\section{III \\ The experience of Asia and Latin American development strategy}

Employment in Latin America presents highly complicated problems which differ from one country to the next, but the major ones are common to most of the region, as is pointed out in a recent publication of the Regional Employment Programme for Latin America and the Caribbean (PREA LC) ${ }^{65}$ They are: (i) a relatively high rate of unemployment; (ii) a high level of under-employment in the agricultural sector; (iii) extensive underprivileged shanty-towns around the cities, swollen by strong migratory flows from the rural zones; (iv) a relatively slow growth of industrial employment, despite quite rapid growth of production. Furthermore, the effects of the sharp growth of the population over the last two decades are beginning to be seen: the labour force is no longer growing at 2.3 per cent, as until recently, but at 2.8 per cent annually. The steep rise in population forecast for the next 25 years gives grounds for assuming that these factors will continue or worsen in the future.

Taking these Latin American facts of life into account, we shall begin by summarizing the main aspects of Japanese and Chinese experience which may be of interest to the region.

The experience analysed above seems to demonstrate that the considerable growth of productivity in the agricul-

\footnotetext{
${ }^{65}$ Regional Employment Programme for Latin America and the Caribbean (PREALC), Employment policy in Latin America, (CC/CTP/2), Santiago, 1974.
}

tural sector occurred without necessarily displacing the manpower employed in the sector. This is interesting because there is a tendency to believe that within a fixed agricultural- surface-area, capital investment (particularly mechanization) tends to replace manpower.

In both Japan and China the cultivated area per person employed in agriculture has always been very small compared with the Latin American countries, but it was possible to increase yields and productivity without appreciably reducing the number of persons employed per unit of cultivated land.

In this connexion we have already mentioned the results obtained in China following the war. As for Japan, the rice yield per hectare rose from 1.8 metric tons in 1868-1882 to 4.0 metric tons in 1956-1960. However, the number of persons employed remained constant at 15 million, with some fluctuations, throughout this long period and the non-agricultural income of peasant families rose progressively, particularly from the middle of the 1950s. An F AO study on Japanese agricultural development finds it highly significant that the country was able to increase productivity in this sector without significantly reducing the total labour force employed in it, while maintaining small-scale agriculture. ${ }^{60}$

66 Takekazu Ogura, (ed.), Agricultural Development in Modern Japan, Japan FAO Association, Tokyo, 1966. 
A number of advantages of rural industrialization should be recalled, although some of them appear to be obvious; it is worth reproducing the point of view expressed in an editorial article of an official Chinese newspaper ${ }^{7} 7$ on small and medium-scale industries in the provinces:

- They involve relatively small investments, and the time which elapses until the factory comes on stream is relatively short;

- They can be built close to the centres of consumption or supply of raw materials and thus they may be suitably located;

- Their products may be diversified according to the specific conditions of the zone;

- They circumvent the problem of the lack of energy and raw materials at the national level, and help to solve the employment problem;

- They do not require imports, since their plant and machinery can be produced within the country.

The same article adds that "the execution of small projects in coalmining, steel and non-ferrous metals and the construction of small power stations, etc., with better orientation and organization, is an important measure by which the country can overcome its backwardness in the production of industrial raw materials, while increasing employment". In a subsequent report further advantages are pointed out:

- Considerable saving in transport costs; - Employment of seasonal labour;

- Co-ordination between industry and agriculture with regard to employment, repair of equipment and

67 Jenmin Jihpao, 16 June 1957 and 12 February 1958, quoted in R. Kojima, "Reappraisal. ...", op. cit. machinery and the supply of inputs for agriculture: in general, a mutual stimulation of the two sectors;

- Less investment on the part of the Central Government, since the local industry can be built by mobilizing material, human and financial resources of the zone, including those of the agricultural co-operatives;

- Higher incomes for the agricultural workers, and broadening of their scientific and technical knowledge;

- Less State expenditure in the construction of urban infrastructure and in the supply of consumer goods, by avoiding an, excessive concentration of the population in cities;

- Reduction of the economic differences between towns and nural areas. The following specific advantages may be seen in the Japanese experience of industrialization:

- The heavy and chemical industries can have a number of favourable direct and indirect effects on employment;

- Labour productivity can be raised in the varios branches of manufacturing industry without carrying out largescale investment, i.e., without a substantial increase in the value of fixed capital per person employed; - The introduction of advanced technology can be made compatible with the absorption of labour in the different manufacturing branches;

- Small and medium-scale industries can absorb large amounts of labour and also achieve technological progress, sustained fixed-capital investment, increased labour productivity and higher exports.

It is not the author's intention to suggest that the experience of these two Asian countries should be directly applied to the Latin American countries; the aim is merely to derive some benefit 
from various aspects of that experience which may provide valuable background material for the formulation of a future Latin American development strategy.

The enormous economic, social and political differences between the countries of Asia and Latin America are well known and will not be discussed here. However, some fundamental points should be recalled in connexion with employment problems and their relationship to industrialization policy.

The two Asian countries analysed above had very serious problems of excess labour, besides the problems stemming from the need to feed their large populations. Latin America is in a better position than they were to tackle the problem, thanks, interalia, to its greater agricultural surface-area and its reserves of various natural resources.

On the other hand, a number of differences not strictly of an economic nature between the countries of Asia and Latin America also give rise to serious reservations about the possibility of applying the Asian experience to other countries. In the case of China, it is obvious that the measures adopted cannot always be separated from the overall socialist economic policy of the country, established in accordance with a specific ideology. However, it would be an error for the countries with different systems to reject the possibility of taking advantage of some aspects of that experience.

It should also be recalled that Japan and China applied very different criteria in respect of foreign trade. While the former from the start sought a vigorous growth of foreign trade, considering it to be one of the main springboards of development and industrialization, China thought otherwise; and the share of exports in the value of its gross domestic product has always been minimal. The role assigned by the Latin American countries to the external sector may differ from those of the two Asian countries, and this would certainly determine to some extent the scope of their industrial and technological policies, inter alia.

Given these general reservations, we shall attempt to make a preliminary appraisal of the possibility of exploiting some aspects of the experience analysed above for the benefit of Latin America.

With regard to the agricultural sector's capacity to absorb labour, there is a striking difference between the number of persons employed per hectare in Latin America and in the two Asian countries. The same may be said of the yield per hectare of some crops. ${ }^{68}$ This difference reveals the enormous potential capacity of the sector to absorb labour productively. Japanese and Chinese experience shows that it is possible to raise productivity per worker and per unit of cultivated land without large-scale investment, and that furthermore this may be done even in small-scale agriculture.

Rural industrialization has the fundamental advantage of absorbing semiemployed labour (or hidden unemployment, to use Nurkse's terminology), without the disadvantages this creates in the large urban industries, which involve

\footnotetext{
68 The area cultivated per agricultural worker was 98.4 hectares in Argentina, 88.5 in Uruguay, 24.7 in Venezuela, 19.9 in Brazil, 16.8 in Mexico, 7.3 in Peru, between 3.0 and 9.1 in the Central American countries, etc. (1DB, Latin American agricultural development in the next decade, Inter-American Development Bank Round Table, Washington, D.C., 1967). The yield of rice per hectare varied between 1.06 and 4.86 tons and that of wheat between 0.55 and 2.55 tons in Latin America in 1964-1965 (CEPAL, Economic Survey of Latin America, 1966, United Nations publication, Sáles No E.68.II.G.1).
} 
longer construction periods, higher investment costs, more skilled labour, etc. In addition, it is costly to transfer labour to the urban centres where these large industries are set up. The fluctuations in the demand for labour in agriculture according to the season and the climatic conditions of each year should also be borne in mind, since they can only be exploited in small local industries.

Nevertheless, rural industrialization could have various disadvantages, as may be seen in the arguments given below which were advanced in China itself. Some of them are summarized in an article which appeared in a Chinese Government newspaper: ${ }^{69}$

(a) Small industries usually need more investment than large industries to produce the same quantity of products;

(b) Production and management costs in small industries are higher than in large industries;

(c) The quality of the products of the small industries is usually inferior to that of the products of the large industries, and the small industries have a smaller capacity to exploit industrial inputs.

However, the same article indicated that the prevailing opinion was that the desirability of rural industrialization should not be judged purely on the basis of short-term costs.

Indeed, the cost does not appear so high if two important advantages of rural industrialization are taken into account: the use of semi-employed labour (which otherwise cannot be used) and the technical training provided to the agricultural workers, since the cost of setting up training schools throughout the country would be immense.

69 Jenmin Jihpas, 12 February 1958, quoted in R. Kojima, "Reappraisal...", op. cit.
Another highly significant aspect of rural industrialization is that it solves to some extent the problem of the difference between the growth of productivity in agriculture and in industry. As is well known, the growth of productivity in the agricultural sector, given specific physical conditions and methods of production, is usually considerably lower than in the manufaoturing sector. This gives rise to differences in the degree of improvement in the standards of living of the workers in the two sectors. Rural industrialization enables agricultural workers to participate to the best of their ability in industrial production and share in the benefits of the growth of productivity in that sector. ${ }^{70}$ Furthermore, since most of the products manufactured by the rural industries are capital goods and inputs for agriculture, rural industrialization in turn enables the productivity of the agricultural sector to be raised.

Needless to say, if some countries of Latin America find it desirable to promote rural industrialization, the features of the process would be very different from those in the Asian countries, since the conditions in the rural zones of Latin America are different, above all as regards the possibilities of supplying inputs for agricultural production both from the

\footnotetext{
70 This problem arose in China in the form of the difference between the wages of industrial and agricultural workers. It cannot be denied, however, that some of this difference stems from relatively unfavourable prices fixed for the agricultural sector. The Government of China has been correcting these prices, raising those of agricultural products and considerably lowering those of manufactures. However, there might also be a difference between the two sectors stemming from the higher growth of productivity per person in one sector compared with the other.
} 
industrial zones of the country and from abroad.

However, it should also be borne in mind that in some rural zones of Latin America the rate of under-employment is relatively high, and the infrastructure is not always sufficient to meet the needs of agriculture at a reasonable transport cost; for the same reasons, their products cannot be marketed in the large towns without raising their price. The exaggerated concentration of population in a small number of large cities (usually the capital of the country) is a predominant factor in various countries of Latin America. This problem could be remedied at least in part by a regional development policy for the various zones at a distance from the capital, in order to create the so-called "poles of development"

With regard to the absorption of labour in the manufacturing sector, it is usually considered that the heavy and chemical industries have a rather limited capacity to generate employment and that the introduction of imported technology, together with investment in capital goods, replaces labour and therefore may have effects on employment which are not necessarily favourable. However, Japanese experience shows that the heavy and chemical industries also have wide fields in which labour is absorbed. Furthermore, these industries present two great advantages: the high potential for raising productivity and the strong demand for their products. These features enable them to gain more funds for investment and the introduction of advanced technology, thus forming a "virtuous circle" and creating good long-term employmẹnt opportunities.

Various studies have shown that the rapid growth of productivity per person employed in almost the entire range of industries resulted hoth in high profits and in a strong and continuous rise in wages and salaries in Japan. The high profits of the enterprises, as well as company, individual and government saving, made possible a boom in large-scale investment which increased the demand for capital goods and industrial inputs. The rapid growth of wages and salaries, despite the high rate of individual saving, constantly increased the demand for consumer goods. Finally, the continuous growth of productivity led to a strongly competitive position in the external market which, together with specialization in the products for which world demand was growing most rapidly, gave rise to the rapid and constant growth of the external demand for Japanese manufactures.

This very vigorous growth of the demand for capital goods, consumer goods and industrial inputs, both within the country and abroad, called for greater investment, fostered through the well-known process of "investment -generated investment". This process, combined with the introduction of advanced technology, caused the steady growth of productivity which in turn created the investment fund (an increasing large source of financing to satisfy investment demand) and this led to the so-called "virtuous circle" of accelerated development. ${ }^{7}$

Latin America seems to possess a number of necessary conditions for entering into a process of accelerated growth of the heavy and chemical

\footnotetext{
"A more detailed account of this phenomenon, as well as broad statistical data and some references, may be found in "Export promotion in Japan and its application to Latin America", Economlc Bulletin for Latin America, Vol. XV, No 1, first half of 1970 (United Nations publication, Sales No E.70.II.G.6).
} 
industries. As we have said, one of the fundamental factors in the rapid industrial growth of Japan was the heavy investment in the manufacturing sector stemming from company and individual saving which, in turn, was made possible by the rapid grow th of productivity. One of the key elements in the process was the rapid incorporation of advanced technology and its adaptation at different levels of productive activities.

Despite its large capacity to absorb advanced technology, Latin America seems to present a considerable technological lag in comparison with the highly industrialized countries, so that it is in a good position to begin an accelerated process of introduction of technology and industrial investment. In Japan, it was impossible to carry out large-scale investment in the desired manner as long as foreign financial resources were not available on favourable terms and as long as the country lacked a substantial source of foreign exchange. Latin America, on the other hand, has the considerable earnings of traditional exports as a source of financial resources.

In Latin America mention has been made of the difficulty created by the small size of the market, but, as Japanese experience shows, there are various branches which do not necessarily need a very large scale of production. In addition, the integration process creates the possibility of installing efficient large-scale industries; thereafter, as they become progressively more competitive, the demand from extra-regional markets may justify an even larger scale of production. The relative abundance of labour will not be a disadvantage in this process, but rather an important advantage if used productively. Perhaps a great effort will have to be made to train labour but, according to the experience of the Asian countries, the smaller industries do not at first require highly-skilled labour. Nevertheless, what is important is that as the industries expand they must incorporate advanced technology and improve the quality of their labour. The relative abundance of labour may be an advantage in specific industrial branches because, if combined with advanced technology, it leads to more competitive products in the international market.

The economic growth of Japan has repeatedly had to be slowed because of balance-of-payments problems. The Latin American countries are in a better position to tackle a problem of this kind because besides the possibilities of increasing exports of manufactures through better competitiveness, most of them have various traditional export products. Some have raw materials needed by the industries -oil, steel, textile raw materials, non-ferrous metals- which Japan had to import. Since in addition Latin America has less need to import food than Japan, the balance-of-payments problem is less serious.

There is a pressing need to recognize the important role which small and medium-scale enterprises could play in the process of expanding the heavy and chemical industries, and to assist them in improving their financing and investment capacity, stimulating technological progress and raising productivity.

Finally, the experience gained in the two Asian countries in other fields might also be exploited by Latin America in such areas as technology (transfer, adaptation and domestic development of technology), export promotion, sectoral development, and assistance to small and medium-scale enterprises, which we have not been able to discuss fully here. 
This study is only a preliminary awaken the interest of economists and of essay on some important points. It stems government and private circles in the from a desire to furnish some back- region, whose knowledge and studies of ground information derived from the those countries are still somewhat experience of two Asian countries which limited. may be of use to Latin America, and to 